\title{
Meteorological Influences on Seasonal Variation of Fine Particulate Matter in Cities over Southern Ontario, Canada
}

\author{
Jane Liu and Siliang Cui \\ Department of Geography and Program in Planning, University of Toronto, 100 St. George Street, Toronto, ON, Canada M5S $3 G 3$
}

Correspondence should be addressed to Jane Liu; janejj.liu@utoronto.ca

Received 21 February 2014; Revised 27 April 2014; Accepted 5 May 2014; Published 6 July 2014

Academic Editor: M. Luisa Sánchez

Copyright (C) 2014 J. Liu and S. Cui. This is an open access article distributed under the Creative Commons Attribution License, which permits unrestricted use, distribution, and reproduction in any medium, provided the original work is properly cited.

\begin{abstract}
This study examines meteorological impacts on seasonal variation of fine particulate matter $\left(\mathrm{PM}_{2.5}\right)$ in southern Ontario, Canada. After analyzing $\mathrm{PM}_{2.5}$ data at 12 cities in the region in 2006, we found that $\mathrm{PM}_{2.5}$ concentrations were $30-40 \%$ higher in summer $\left(7-15 \mu \mathrm{g} / \mathrm{m}^{3}\right)$ than in winter $\left(4-11 \mu \mathrm{g} / \mathrm{m}^{3}\right)$. High $\mathrm{PM}_{2.5}$ episodes occurred more frequently in warmer seasons. Analyses of surface meteorology, weather maps, and airflow trajectories suggest that these $\mathrm{PM}_{2.5}$ episodes were often related to synoptic transport of pollutants from highly polluted areas in the United States. The southerly or southwesterly winds associated with midlatitude cyclones play an important role in such transport. A typical weather pattern favoring the transport is suggested. When it was hot, humid, and stagnant with southerly or southwesterly winds, the likelihood of high $\mathrm{PM}_{25}$ occurrences was high. The Greater Golden Horseshoe and Southwestern Ontario regions had higher $\mathrm{PM}_{2.5}\left(6-12 \mu \mathrm{g} / \mathrm{m}^{3}\right.$ annually) than the northern region $\left(4-6 \mu \mathrm{g} / \mathrm{m}^{3}\right)$, reflecting combined effects of meteorology, regional transport, and local emissions. In the future, $\mathrm{PM}_{2.5}$ transport from the United States will likely increase in abundance because of possible prolonged accumulation at the pollution sources as the frequency of the midlatitude cyclones may reduce under climate change.
\end{abstract}

\section{Introduction}

Particulate matter (PM) is a combination of fine solids and liquid droplets suspended in the air. PM comes from a variety of sizes, materials, and chemicals. $\mathrm{PM}_{2.5}$ is fine particulate matter with aerodynamic diameter less than $2.5 \mu \mathrm{m}$, which is composed of sulfate, nitrate, ammonium, hydrogen ion, black carbon, organic compounds, metals, and particle-bound water. Epidemiological studies suggested that both acute exposures and chronic exposures of PM impose a significant adverse health impact on people [1], since PM can be inhaled into lungs and reach deep into the cardiovascular system. The health and environment damage caused by ground level PM and ozone, which can lead to formation of smog, was valued at 9.6 billion dollars in Ontario during 2003 [2, 3]. Air pollution caused 1,925 premature deaths, 9,807 hospital admissions, 45,250 emergency room visits, and 46, 445, 663 minor illnesses in Ontario during 2000 based on a study conducted by the Ontario Medical Association $[4,5]$.

Southern Ontario is the most populous region in Canada and often experiences the highest level of $\mathrm{PM}_{2.5}$ in Canada
[3]. Previous findings identified that ambient $\mathrm{PM}_{2.5}$ concentrations at rural locations in the region were largely affected by nonlocal sources originating in the United States of America (USA) and Canada, while at urban locations like the greater Toronto area, the local emissions were $30-35 \%$ during the warm seasons (May-September) of 1997 and 1998 [6]. Furthermore, it was reported that transport of $\mathrm{PM}_{2.5}$ from the Ohio River Valley is often associated with the highest $\mathrm{PM}_{2.5}$ concentrations in southern Ontario [6-8]. A close examination on the meteorological conditions that lead to high $\mathrm{PM}_{2.5}$ was recommended [6].

Meteorology can greatly influence air pollution [9]. The relationship between meteorological conditions and $\mathrm{PM}_{2.5}$ is complicated due to the diversities of $\mathrm{PM}_{2.5}$ components and the complex atmospheric processes involved. Some earlier studies examined PM-meteorology relationships for individual meteorological variables including temperature, relative humidity, wind speed, and wind direction [9-11]. Others considered combined effects of these variables and the synoptic-scale meteorological impacts on $\mathrm{PM}_{2.5}[6,9,12]$. Cold frontal passages associated with midlatitude cyclones 


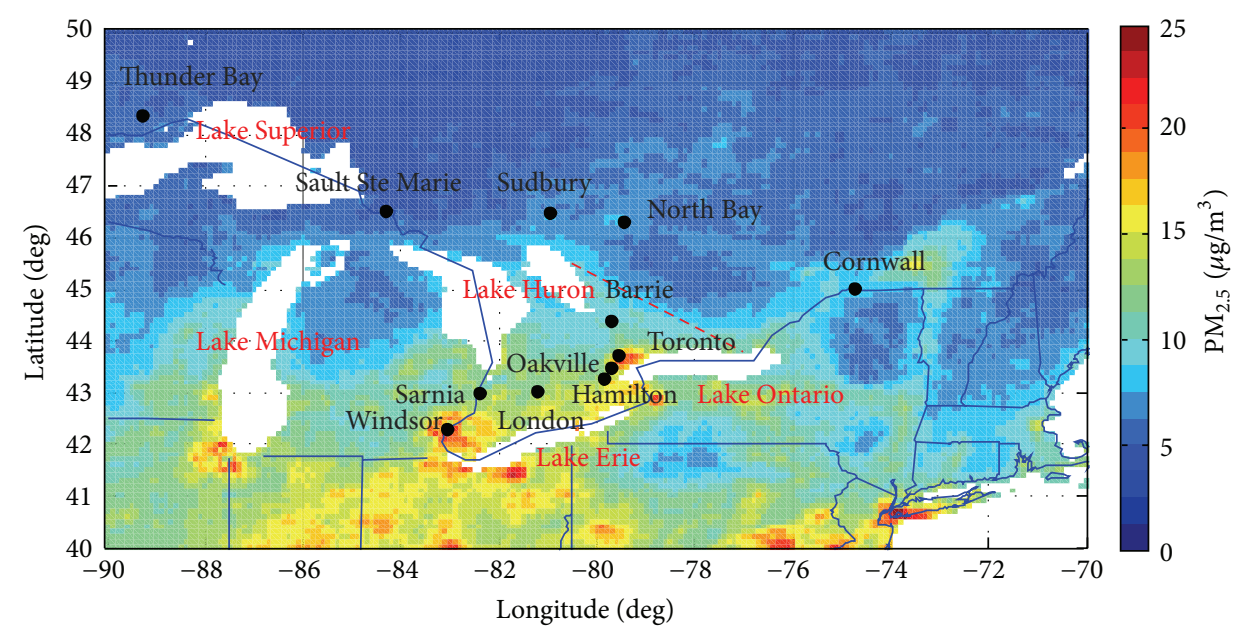

(a)

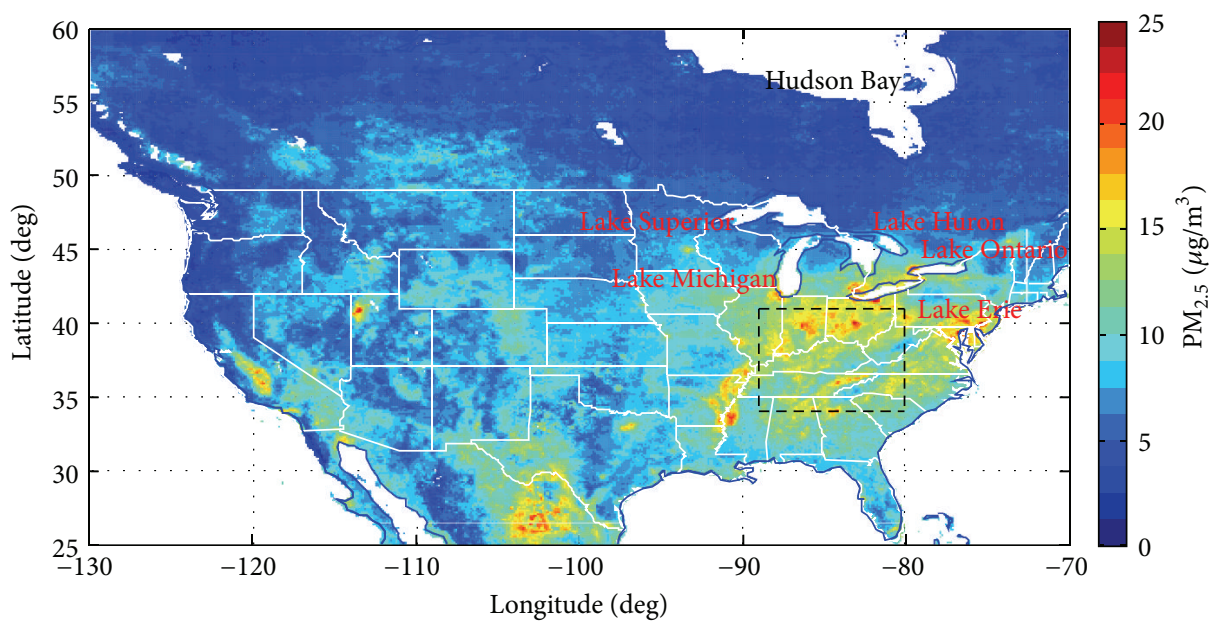

(b)

FIGURE 1: (a) Study area including 12 cities in Ontario, Canada, overlaid with the annual mean $\mathrm{PM}_{2.5}$ concentrations $\left(\mu \mathrm{g} / \mathrm{m}^{3}\right)$ derived from satellite measurements between 2001 and 2006 at $0.1^{\circ} \times 0.1^{\circ}$ resolution [22]. The Greater Golden Horseshoe and Southwestern Ontario regions are within the area between the dashed line and the boundary of the two countries. (b) $\mathrm{PM}_{2.5}$ distribution over North America from the same data source as in (a). The boxed area approximately indicates the Ohio River Valley region. The blue lines in (a) and white lines in (b) delineate the boundary between Canada and the United States of America (USA) and the state boundaries of USA.

provide pollutant ventilation and lead to $\mathrm{PM}_{2.5}$ variability in eastern North America, Europe, and eastern Asia [9, 11, 13, 14]. The cold fronts were found to drive the overall correlations of $\mathrm{PM}_{2.5}$ with temperature and relative humidity in eastern United States [9]. Due to global warming, a reduction in cyclone frequency may cause prolonged stagnation and eventually more frequent pollutant episodes during the summertime in the northeastern United States $[15,16]$.

To enhance our understanding of the meteorological impacts on $\mathrm{PM}_{2.5}$ for the purpose of developing air quality forecast and control strategies in Ontario, this study has the following specific objectives: (1) to characterize seasonal and spatial variations of $\mathrm{PM}_{2.5}$ over southern Ontario, (2) to understand the underlying mechanisms for these variations, (3) to inspect influences of synoptic meteorological processes, especially midlatitude cyclones, on high $\mathrm{PM}_{25}$ episodes, and (4) to examine the likelihood of meteorological conditions for clear and heavy polluted air, respectively, in southern Ontario.

In the following, the four objectives will be addressed in Section 3 after a description of the study area and data in Section 2. Summary and conclusions will be provided in Section 4.

\section{Study Area and Data Description}

2.1. Study Area. The study area (Figure 1(a)) includes southern Ontario province of Canada. The area is mainly within the Great Lakes-St. Lawrence Lowlands region [17]. The area is bounded by Lakes Ontario and Erie and Ohio River Valley 
TABle 1: Characteristics for the 12 Ontarian cities in 2006. The cities are ordered by descending latitude see Figure 1(a).

\begin{tabular}{|c|c|c|c|c|c|c|c|}
\hline City & Lat. $\left(^{\circ}\right)$ & Lon. $\left({ }^{\circ}\right)$ & Elevation (m) & Population & $\begin{array}{l}\text { Annual average of } \mathrm{PM}_{2.5} \\
\text { concentration }\left(\mu \mathrm{g} / \mathrm{m}^{3}\right)\end{array}$ & Characteristics & $\begin{array}{c}\text { Annual total emission } \\
\text { (tons } / y)\end{array}$ \\
\hline Thunder Bay & 48.38 & -89.29 & 192 & 109,140 & 4.80 & Urban & 366 \\
\hline Sault Ste. Marie & 46.53 & -84.31 & 244 & 74,948 & 5.23 & Urban & 376 \\
\hline Sudbury & 46.48 & -80.96 & 260 & 21,392 & 4.65 & Urban & 47 \\
\hline North Bay & 46.32 & -79.45 & 219 & 53,996 & 4.93 & Urban & 23 \\
\hline Cornwall & 45.02 & -74.74 & 55 & 45,965 & 6.46 & Urban & 39 \\
\hline Barrie & 44.38 & -79.70 & 226 & 128,430 & 6.64 & Urban & 8 \\
\hline Toronto & 43.71 & -79.54 & 141 & $2,503,281$ & 8.07 & Metropolitan & 474 \\
\hline Oakville & 43.49 & -79.70 & 165 & 164,613 & 7.34 & Urban & 8 \\
\hline Hamilton & 43.26 & -79.91 & 96 & 504,559 & 8.20 & Industrial, urban & 1416 \\
\hline London & 43.01 & -81.21 & 270 & 352,395 & 6.91 & Urban & 66 \\
\hline Sarnia & 42.98 & -82.41 & 179 & 71,419 & 11.28 & Industrial & 723 \\
\hline Windsor & 42.32 & -83.04 & 176 & 216,473 & 9.18 & Industrial, urban & 287 \\
\hline
\end{tabular}

to the south [4] and the Hudson Bay to the North. The terrain in the area is very smooth, ranging from 200 to 500 meters [18], making air pollutants easy to be transported around $[12,19]$. The Greater Golden Horseshoe and Southwestern Ontario regions, where urbanization and industrialization have rapidly taken place, extend from Long Point in the south, through the Niagara, Hamilton, and Waterloo Regions, to the east of the greater Toronto area. The climate there is one of the mildest regions of Canada. Since Ontario lies in the midlatitudes, a continental climate affects this region [20]. Under the strong influence of the jet stream, Ontario experiences wide variations in meteorology, such as frequent passages of high and low pressure systems [20]. For example, Toronto often experiences mild air masses in the summer [21], including persistent high pressure systems and sunny and warm conditions [21]. In winter, dominant high pressure systems in the northern Canada bring dry polar air mass to Toronto in about $30 \%$ of the days, with northerly winds and little to no cloud covers [21]. Such variations in meteorology lead to diverse changes in PM at our study sites discussed below.

2.2. Hourly $P M_{2.5}, P_{2.5}$ Emission, and Population Data. The ambient hourly $\mathrm{PM}_{2.5}$ concentration data were collected from the Air Quality Ontario of the Ontario Ministry of the Environment (http://airqualityontario.com/history/). This network has 40 stations across the province that measure selected particulate and gaseous pollutants among $\mathrm{PM}_{2.5}$, $\mathrm{SO}_{2}, \mathrm{NO}, \mathrm{NO}_{2}, \mathrm{NO}_{x}, \mathrm{CO}$, and $\mathrm{O}_{3}$ at the ground level on hourly bases since 2003 . The $\mathrm{PM}_{2.5}$ is measured with tapered element oscillating microbalance (TEOM) 1400AB operated at $30^{\circ} \mathrm{C}$ with SES (http://airqualityontario.com/history/). We selected 12 cities with different geographical locations, city characteristics, populations, $\mathrm{PM}_{2.5}$ emissions, and industrial activities (Figure 1(a), Table 1). Windsor, Sarnia, London, Hamilton, Oakville, Toronto, and Barrie are located in the southern part of the study area, while Thunder Bay, Sault Ste. Marie, Sudbury, and North Bay are located in the north (Figure 1(a)). All hourly $\mathrm{PM}_{2.5}$ data were screened by removing the missing data labeled with -999 and invalid data labeled with 9999 from the original dataset. Mean $\mathrm{PM}_{2.5}$ values were calculated daily, monthly, and annually. The seasonal means were taken for spring (March, April, and May), summer (June, July, and August), fall (September, October, and November), and winter (December, January, and February). The number of polluted days was categorized based on daily $\mathrm{PM}_{2.5}$ concentrations, with an increment of $5 \mu \mathrm{g} / \mathrm{m}^{3}$.

In Table 1, the population data were acquired from the population and dwelling counts in the 2006 Community Profile in the Statistics Canada's 2006 Census (http://www12 statcan.ca/census-recensement/index-eng). The annual emissions were calculated by summing up all sources based on the Facility Report in the National Pollutant Release Inventory (NPRI) (http://www.ec.gc.ca/inrp-npri/). Annual mean $\mathrm{PM}_{2.5}$ concentrations in 2006 are also listed. Cities are ordered by decreasing latitude (the same for Tables 2-3 and Figures 2-4).

2.3. Surface Meteorological Data and Weather Maps. The hourly meteorological measurements in 2006 at the surface, including air temperature, relative humidity, wind speed, wind direction, and the surface pressure, were collected from the National Climate Data and Information Archive under the Environment Canada (http://climate.weatheroffice.gc.ca/ climateData/canada_e.html). All selected cities had hourly meteorological data except for Cornwall and Oakville where only daily meteorological data were available. The missing values coded as blanks were removed. The daily weather maps were acquired from the Weather Prediction Center, National Weather Service (http://www.hpc.ncep.noaa.gov/ dailywxmap/). The daily surface weather map provides the station analysis at 7:00 am, EST. 


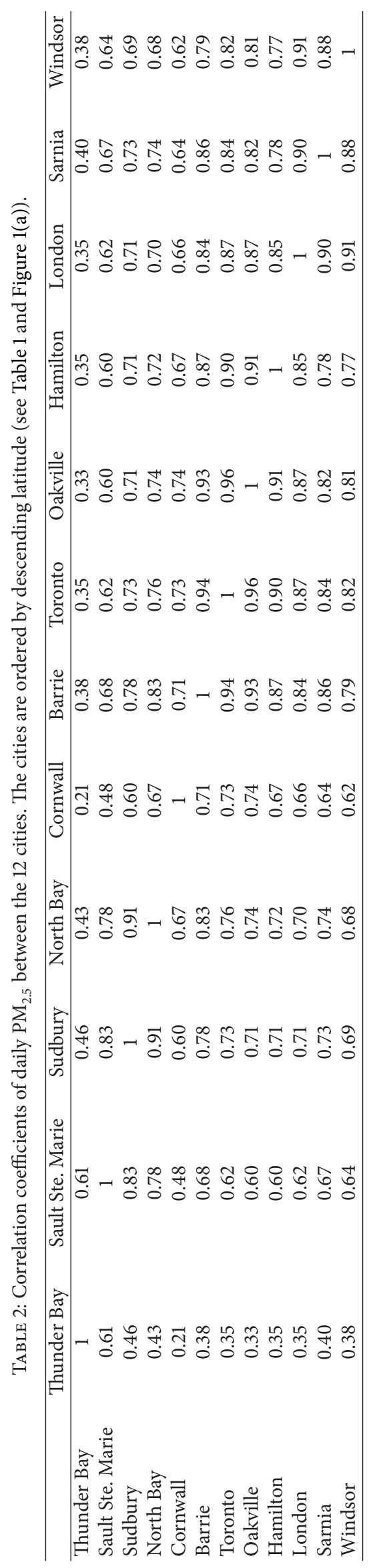


TABLE 3: Comparison of mean hourly meteorological conditions at the surface (temperature, humidity, surface pressure, and wind speeds) for both clear $\left(\mathrm{PM}_{2.5} \leq 5 \mu \mathrm{g} / \mathrm{m}^{3}\right)$ and polluted $\left(\mathrm{PM}_{2.5} \geq 30 \mu \mathrm{g} / \mathrm{m}^{3}\right)$ times at cities in southern Ontario. The cities are ordered by descending latitude (see Table 1 and Figure 1(a)).

\begin{tabular}{|c|c|c|c|c|c|c|c|}
\hline City & $\begin{array}{c}\mathrm{PM}_{2.5} \text { range } \\
\left(\mu \mathrm{g} / \mathrm{m}^{3}\right)\end{array}$ & $\begin{array}{c}\mathrm{PM}_{2.5} \\
\left(\mu \mathrm{g} / \mathrm{m}^{3}\right)\end{array}$ & $\begin{array}{c}\text { Temperature } \\
\left({ }^{\circ} \mathrm{C}\right)\end{array}$ & $\begin{array}{l}\text { Relative humidity } \\
(\%)\end{array}$ & $\begin{array}{c}\text { Pressure } \\
(\mathrm{hPa})\end{array}$ & $\begin{array}{c}\text { Wind speed } \\
(\mathrm{km} / \mathrm{h})\end{array}$ & Number of hours \\
\hline \multirow{2}{*}{ Thunder Bay } & $0-5$ & 2.5 & 17.7 & 68.4 & 992.2 & 12.0 & 1222 \\
\hline & $30-55$ & 36.4 & 17.5 & 80.1 & 990.2 & 6.9 & 19 \\
\hline \multirow{2}{*}{ Sault Ste. Marie } & $0-5$ & 2.6 & 16.6 & 67.9 & 994.3 & 10.8 & 1161 \\
\hline & $30-55$ & 35.3 & 19.6 & 69.9 & 991.0 & 6.9 & 30 \\
\hline \multirow{2}{*}{ Sudbury } & $0-5$ & 6.4 & 18.3 & 69.1 & 974.3 & 11.9 & 2165 \\
\hline & $30-55$ & 33.0 & 25.8 & 63.3 & 971.4 & 16.8 & 10 \\
\hline \multirow{2}{*}{ North Bay } & $0-5$ & 2.3 & 16.3 & 71.4 & 972.3 & 11.7 & 1223 \\
\hline & $30-55$ & 32.4 & 22.5 & 73.0 & 968.9 & 12.5 & 19 \\
\hline \multirow{2}{*}{ Barrie } & $0-5$ & 2.7 & 17.0 & 71.2 & 978.0 & 11.6 & 921 \\
\hline & $30-55$ & 34.9 & 22.8 & 76.2 & 977.4 & 9.4 & 54 \\
\hline \multirow{2}{*}{ Toronto } & $0-5$ & 3.0 & 19.1 & 64.4 & 995.8 & 18.2 & 623 \\
\hline & $30-55$ & 35.8 & 24.0 & 75.8 & 991.4 & 14.3 & 110 \\
\hline \multirow{2}{*}{ Hamilton } & $0-5$ & 2.7 & 18.1 & 72.1 & 988.6 & 13.6 & 735 \\
\hline & $30-55$ & 35.2 & 22.8 & 78.6 & 984.8 & 15.0 & 128 \\
\hline \multirow{2}{*}{ London } & $0-5$ & 2.9 & 18.4 & 69.1 & 984.4 & 11.2 & 727 \\
\hline & $30-55$ & 33.0 & 22.3 & 81.0 & 979.7 & 11.0 & 97 \\
\hline \multirow{2}{*}{ Sarnia } & $0-5$ & 4.0 & 17.6 & 73.6 & 989.1 & 18.4 & 317 \\
\hline & $30-55$ & 37.3 & 24.1 & 75.6 & 991.7 & 12.0 & 204 \\
\hline \multirow{2}{*}{ Windsor } & $0-5$ & 3.0 & 20.4 & 63.4 & 994.8 & 14.0 & 485 \\
\hline & $30-55$ & 35.1 & 24.9 & 71.9 & 991.6 & 12.6 & 156 \\
\hline
\end{tabular}

\section{Results and Discussion}

3.1. Temporal Variation of $P M_{2.5}$ in Ontario. Figure 2 shows the daily variation of $\mathrm{PM}_{2.5}$ concentrations in 2006 at the 12 cities. Three 24-hour $\mathrm{PM}_{2.5}$ standards are also indicated, including $25 \mu \mathrm{g} / \mathrm{m}^{3}$ by the World Health Organization (WHO) (a level based on relationship between 24-hour and annual PM levels. In addition to other health benefits, the level lowers the risk of premature mortality by approximately $6 \%$ relative to $\mathrm{PM}_{2.5}$ being $35 \mu \mathrm{g} / \mathrm{m}^{3}$, http://www.who.int/), $30 \mu \mathrm{g} / \mathrm{m}^{3}$ by the Canadian-Wide Standards (CWS) (a target by 2010 with achievement based on the 98th percentile measurement annually, averaged over 3 consecutive years, http://www.ec.gc.ca/rnspa-naps/), and $35 \mu \mathrm{g} / \mathrm{m}^{3}$ by Environmental Protection Agency (EPA) of the United States (a target with achievement based on the 98th percentile measurement annually, averaged over 3 years, http://www.epa.gov/air/criteria.html).

The daily $\mathrm{PM}_{2.5}$ level ranged from 0 to $40 \mu \mathrm{g} / \mathrm{m}^{3}$. All the cities experienced significant daily variation in $\mathrm{PM}_{2.5}$, with a combination of low background $\mathrm{PM}_{2.5}$ concentrations and frequent occurrences of $\mathrm{PM}_{2.5}$ episodes. Seasonal $\mathrm{PM}_{2.5}$ concentrations at the 12 cities are shown in Figure 3 for spring, summer, fall, and winter in 2006. For all the cities, the mean $\mathrm{PM}_{2.5}$ concentrations were the highest in summer, ranging from 7 to $15 \mu \mathrm{g} / \mathrm{m}^{3}$, followed by spring, fall, and winter when $\mathrm{PM}_{2.5}$ was between 4 and $11 \mu \mathrm{g} / \mathrm{m}^{3}$.

High $\mathrm{PM}_{2.5}$ episodes occurred more frequently in warmer seasons (Figure 4). The number of days with
$\mathrm{PM}_{2.5}>20 \mu \mathrm{g} / \mathrm{m}^{3}$ in summer was 10-20 days at the southern cities, while the number in winter was 2 days at Sarnia and zero for the rest (Figure 4). The numbers of days with $\mathrm{PM}_{2.5}$ larger than other levels were also larger in summer (Figure 4). The high frequency of $\mathrm{PM}_{2.5}$ episodes in summer is likely one of the reasons for high $\mathrm{PM}_{2.5}$ levels in the season. These episodes were usually associated with synoptic weather processes, as to be discussed in Section 3.3.

Another reason for high $\mathrm{PM}_{2.5}$ in warmer seasons may be related to air temperature. Air temperature can influence chemical processes that manipulate $\mathrm{PM}_{2.5}$ components, especially on $\mathrm{ASO}_{4}$ component [23]. Increasing temperature can increase sulfur dioxide $\left(\mathrm{SO}_{2}\right)$ oxidation and sulfate concentrations and reduce nitrate concentrations $[6,24-$ 26]. For example, both Toronto and Windsor have higher ammonium sulfate $\left(\mathrm{ASO}_{4}\right)$ concentrations in summer than in winter, while the ammonium nitrate $\left(\mathrm{ANO}_{3}\right)$ concentrations in the two cities are lower (close to zero) in warmer seasons [19]. Additionally, temperature can influence PM emissions greatly, due to its impact on biogenic emissions, road mobile emissions [27], and wildfire emissions [24]. These influences cause higher organic matters and elemental carbon contents in Toronto and Windsor in summer [19].

3.2. Spatial Variation of $P M_{2.5}$ in Southern Ontario. $P M_{2.5}$ concentrations derived from the satellite instruments MODIS (The Moderate-Resolution Imaging Spectroradiometer) and MISR (The Multi-Angle Imaging Spectroradiometer) [22] 

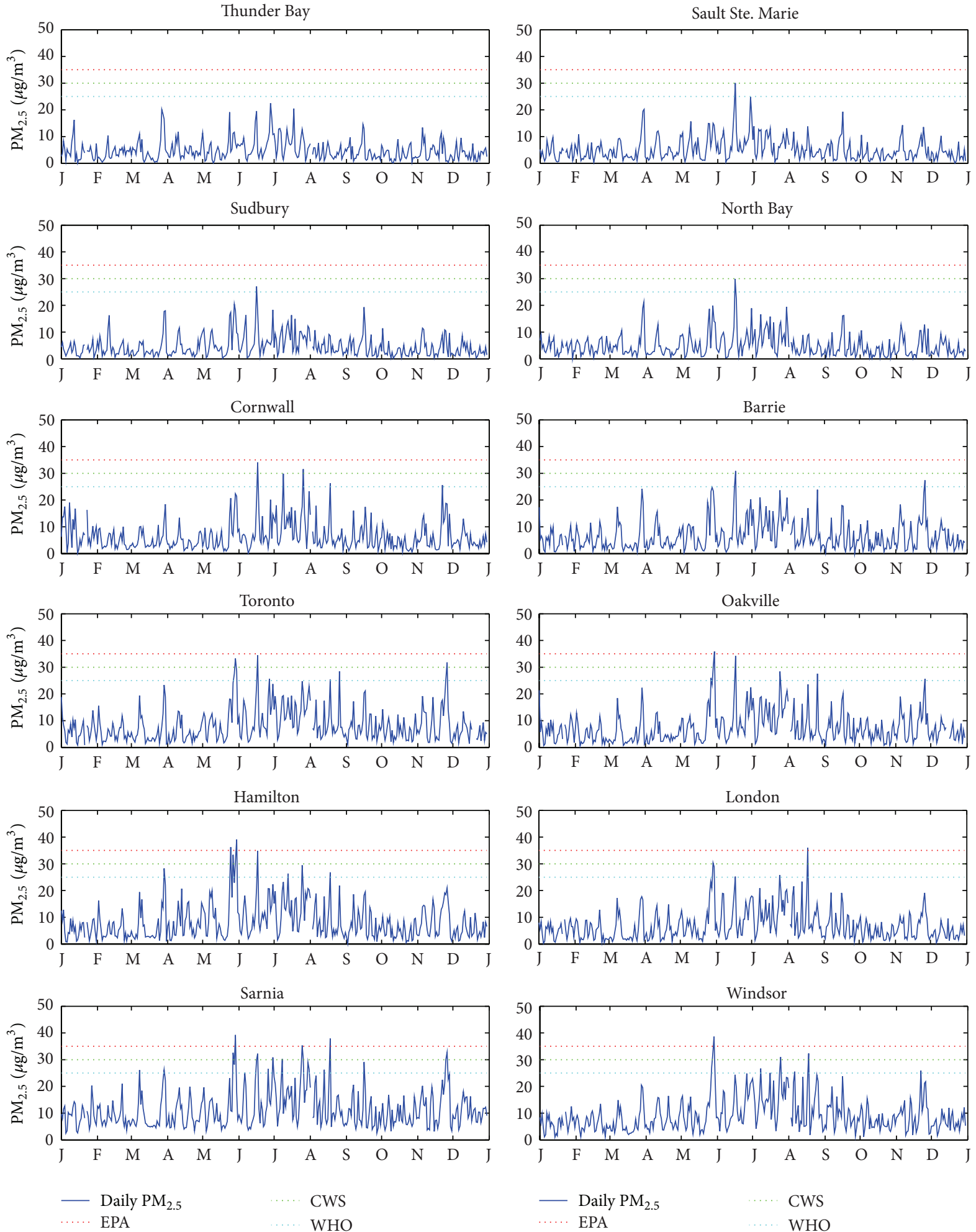

FIGURE 2: Daily variation of $\mathrm{PM}_{2.5}$ at 12 cities in Ontario in 2006, with three 24-hour guidelines: $25 \mu \mathrm{g} / \mathrm{m}^{3}$ by the World Health Organization (WHO) guideline, $30 \mu \mathrm{g} / \mathrm{m}^{3}$ by the Canadian Wide Standards (CWS), and $35 \mu \mathrm{g} / \mathrm{m}^{3}$ by the Environmental Protection Agency (EPA) of USA guideline. The $x$-axis indicates months of the year by their initial letters. The cities are ordered by descending latitude (see Table 1 and Figure 1(a)). 


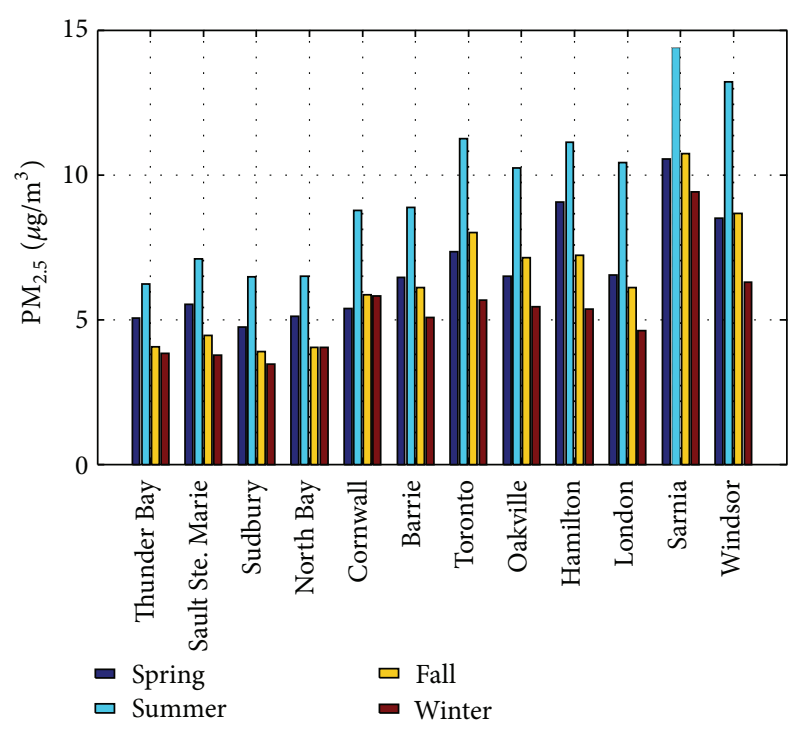

FIgURE 3: $\mathrm{PM}_{2.5}$ concentrations $\left(\mu \mathrm{g} / \mathrm{m}^{3}\right)$ in spring (March, April, and May), summer (June, July, and August), fall (September, October, and November), and winter (December, January, and February) at the 12 Ontarian cities in 2006 . The cities are ordered by descending latitude (see Table 1 and Figure 1(a)).

over North America are shown in Figure 1(b). $\mathrm{PM}_{2.5}$ concentrations were estimated with an equation of $\mathrm{PM}_{2.5}=\eta \times$ AOD, where AOD is the satellite-based aerosol optical depth and $\eta$ is coefficient related to aerosol size, aerosol type, diurnal variation, relative humidity, and the vertical structure of aerosol extinction [22]. A global chemical transport model, namely, GEOS-Chem, was used to calculate the daily global distribution of $\eta$ [22].

The Greater Golden Horseshoe and Southwestern Ontario regions often experience the highest levels of $\mathrm{PM}_{2.5}$ in Canada, as demonstrated in Figure 1(b). Outside the regions, the $\mathrm{PM}_{2.5}$ concentrations are low. Note that over the Ohio River Valley, south of the Great Lakes region, annual mean $\mathrm{PM}_{2.5}$ reaches $20 \mu \mathrm{g} / \mathrm{m}^{3}$ in some areas. The highly polluted air there can significantly affect $\mathrm{PM}_{2.5}$ levels in Ontario, which was suggested in earlier studies $[6,28,29]$ and will be discussed in detail in Section 3.3.

$\mathrm{PM}_{2.5}$ concentrations in southern Ontario varied greatly from the south to the north (Figure 1(a)). Among the 12 cities, Toronto, Hamilton, Sarnia, and Windsor had highest $\mathrm{PM}_{2.5}$ levels, with annual $\mathrm{PM}_{2.5}$ being $8-12 \mu \mathrm{g} / \mathrm{m}^{3}$ in 2006 (Table 1, Figure 1), due to their high local $\mathrm{PM}_{2.5}$ emissions (300-1400 tons/year, Table 1) and their southern locations where transport of $\mathrm{PM}_{2.5}$ from USA was significant. In contrast, at the northern cities, including Thunder Bay, Sault Ste. Marie, Sudbury, and North Bay, $\mathrm{PM}_{2.5}$ levels were the lowest $\left(4-6 \mu \mathrm{g} / \mathrm{m}^{3}\right.$, Table 1 , Figure 1), because of their locations away from the transport pathways of $\mathrm{PM}_{2.5}$ from the south, even though the local $\mathrm{PM}_{2.5}$ emissions in Sault Ste. Marie and Thunder Bay were comparable with Toronto and Windsor ( 370 tons/year, Table 1). In between, mean $\mathrm{PM}_{2.5}$ levels in London, Oakville, Barrie, and Cornwall were intermediate
(6-8 $\mu \mathrm{g} / \mathrm{m}^{3}$, Table 1 , Figure 1) and were influenced mainly by surrounding high $\mathrm{PM}_{2.5}$ sources and regional transport of $\mathrm{PM}_{2.5}$ from USA, since the local $\mathrm{PM}_{2.5}$ emissions were low (8-66 tons/year, Table 1) due to their small industry activities and intermediate population (Table 1).

The $\mathrm{PM}_{2.5}$ values derived from satellite data are generally consistent with the $\mathrm{PM}_{2.5}$ observations from the surface (Figure 1(a), Table 1), with low $\mathrm{PM}_{2.5}$ at northern cities (Thunder Bay, Sudbury, North Bay, and Sault Ste. Marie), high $\mathrm{PM}_{2.5}$ in southern metropolitan and cities with heavy industrial activities (Toronto, Hamilton, and Windsor), and intermediate $\mathrm{PM}_{2.5}$ for the middle-sized cities (Barrie, London, and Oakville). However, the $\mathrm{PM}_{2.5}$ annual mean for Sarnia from the ground measurement was the highest $\left(11 \mu \mathrm{g} / \mathrm{m}^{3}\right)$ among the 12 cities and this is not reflected in the satellite image (Figure 1(a)), perhaps due to the coarse horizontal resolution $\left(0.1^{\circ}\right)$ of the satellite data.

The eight cities with high and intermediate $\mathrm{PM}_{2.5}$ concentrations lie on the corridor along southern Ontario and the highly polluted industrial areas in USA and Canada (Figure 1) $[3,6]$, indicating that regional transport of $\mathrm{PM}_{2.5}$ contributes significantly to ambient $\mathrm{PM}_{2.5}$ at these cities $[7,30]$. The strong influence of transport of $\mathrm{PM}_{2.5}$ over a large area in Ontario is also captured in Figures 2 and 5, as high $\mathrm{PM}_{2.5}$ episodes are found to have happened at several stations at the same time. This is further confirmed in Table 2 which lists the correlation coefficients of daily $\mathrm{PM}_{2.5}$ in 2006 among the 12 cities. Starting from Toronto, the correlations between Toronto and the closest cities to it (Oakville, Barrie, and Hamilton) are highest $(r>0.9) . \mathrm{PM}_{2.5}$ at Toronto correlates intermediately $(0.82<r<0.87)$ with that at the southern cities (London, Sarnia, and Windsor) and correlates the least with that at the northern cities $(r<0.73)$. Among the northern cities, Thunder Bay has the lowest correlation with most cities $(r<0.46)$ except for the closest city Sault Ste. Marie $(r=0.61)$. For other northern cities, the correlation coefficient is high between cities that are close to each other. It is also high between these cities and Toronto, implying that they may be under the same influences. The correlation coefficient between Toronto and these cities is 0.7-0.8 for North Bay, Cornwall, and Sudbury, 0.62 for Sault Ste. Marie, and 0.35 for Thunder Bay. The $\mathrm{PM}_{2.5}$ in the southern cities (London, Sarnia, and Windsor) correlates strongly with each other $(r>0.88)$. They correlate with the $\mathrm{PM}_{2.5}$ at Toronto more closely $(r>0.79)$ than that at the northern cities $(0.35<$ $r<0.74)$.

3.3. Synoptic Meteorology Influence on $P M_{2.5}$ Episodes: An Example in June 2006. In 2006, 6 smog advisories covering 17 days were issued when $\mathrm{PM}_{2.5}$ or ozone or both were high, including May 27-31, June 16-19, July 16-17, July 27-28, July 31-August 2, and August 27. The number of the smog advisory days was 17 in 2006, close to its mean between 2006 and 2011. At Toronto, daily $\mathrm{PM}_{2.5}$ concentrations exceeded $25 \mu \mathrm{g} / \mathrm{m}^{2}$ during May 27-31, June 16-19, July 27-28, and August 27. The $\mathrm{PM}_{2.5}$ concentrations in the southern cities (Hamilton, Oakville, Barrie, Sarnia, Windsor, and London) also peaked more or less during these days (Figures 2 and 5), suggesting 


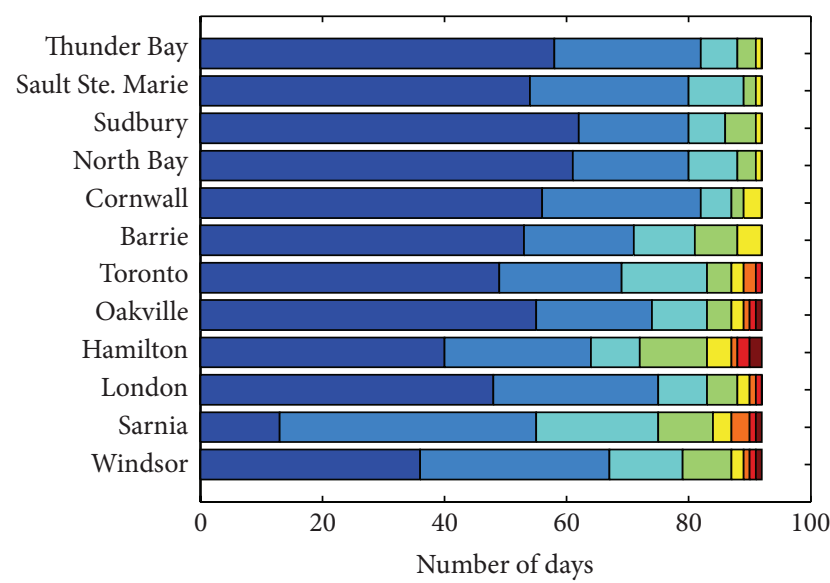

(a) Spring
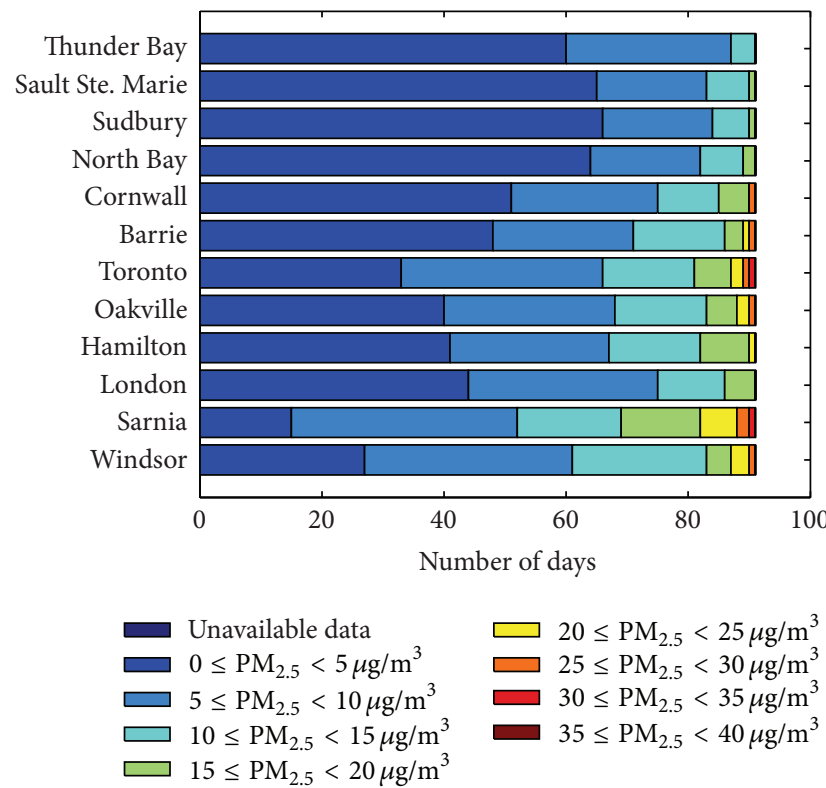

(c) Fall

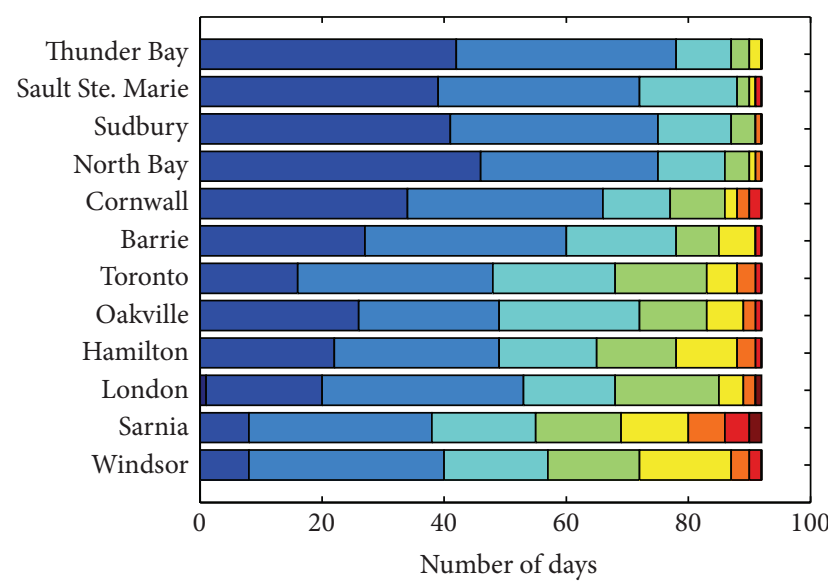

(b) Summer
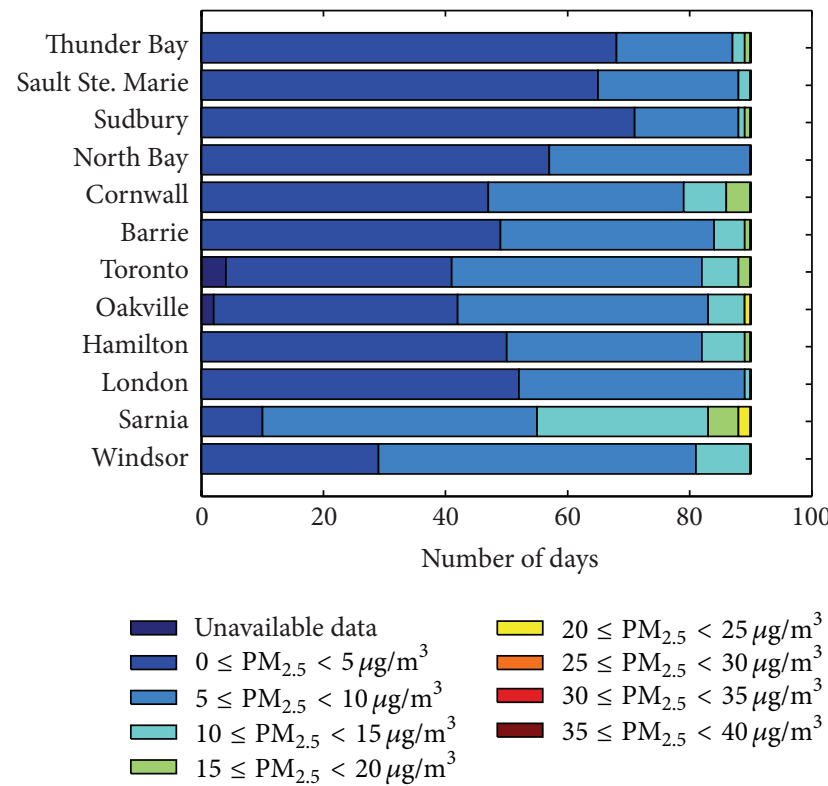

(d) Winter

FIgURE 4: The number of days for daily $\mathrm{PM}_{2.5}$ at 7 levels in spring, summer, fall, and winter at the 12 Ontarian cities in 2006 . The cities are ordered by descending latitude (see Table 1 and Figure 1(a)).

that the region might be experiencing similar meteorological influences, on $\mathrm{PM}_{2.5}$ production and mission (mostly related to air temperature) and/or on transport (mostly related to winds). In the north, Cornwall was most influenced during these periods as it was on the pollution transport corridors, while the other northern cities were influenced one or two times during the $\mathrm{PM}_{2.5}$ episodes.

After analyzing weather maps and surface meteorological data, we found that the weather patterns in these high $\mathrm{PM}_{2.5}$ episodes were quite similar. In the following, we take Toronto during June 16-19 as an example to illustrate the synoptic meteorology influence on high $\mathrm{PM}_{2.5}$ episodes (Figures 6, 7, and 8).

On June 18, 2006, Toronto experienced daily $\mathrm{PM}_{2.5}$ of $34.5 \mu \mathrm{g} / \mathrm{m}^{3}$, the highest value in the year (Figure 2). The $\mathrm{PM}_{2.5}$ level was gradually built up frombeing $1 \mu \mathrm{g} / \mathrm{m}^{3}$ at 2:00 on June
12 to $40 \mu \mathrm{g} / \mathrm{m}^{3}$ at 21:00 on June 18,2006 . After that, $\mathrm{PM}_{2.5}$ concentrations reduced promptly on June 19 and returned to low levels below $10 \mu \mathrm{g} / \mathrm{m}^{3}$. This development is shown in Figure 6 with hourly $\mathrm{PM}_{2.5}$, along with temperature $\left({ }^{\circ} \mathrm{C}\right)$, relative humidity $(\%)$, wind direction $\left({ }^{\circ}\right)$, wind speed $(\mathrm{km} / \mathrm{h})$, and surface pressure (hPa) from June 16 to 22,2006 . The entire process can be divided into four phases (Figure 6) based on the surface meteorology (Figure 6) and weather pattern (Figure 7).

In phase 1 between June 12 and 15, 2006, a high pressure system gradually established over Ontario and $\mathrm{PM}_{2.5}$ remained low $\left(<10 \mu \mathrm{g} / \mathrm{m}^{3}\right)$. The surface air temperature gradually increased and the air became drier and drier. The surface pressure over Toronto was stable between 995 and $1000 \mathrm{hPa}$, with slow north winds that carried clean air into Toronto (Figure 6). 


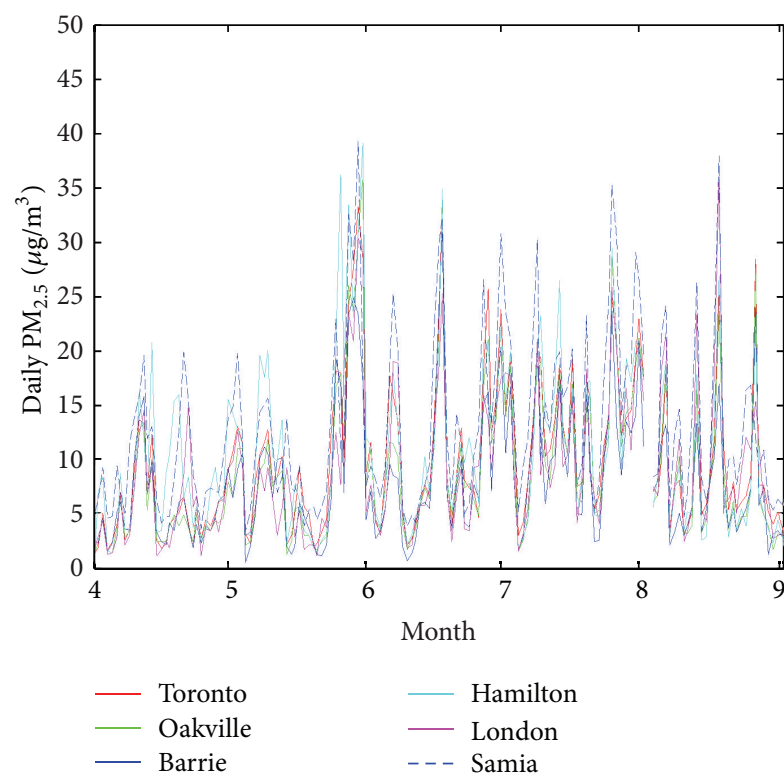

Figure 5: Daily $\mathrm{PM}_{2.5}$ at Toronto and five cities where $\mathrm{PM}_{2.5}$ values are highly correlated with that at Toronto (see Table 2) from April to September 2006.

In phase 2, a low pressure system (cyclone) began to form in the central Canada and a high pressure system (anticyclone) moved towards the east coast of North America between June 15 and June 18, 2006. As the entire weather system shifted to the east, surface pressure gradually decreased from 1001.7 to $993.7 \mathrm{hPa}$. On June 17, anticlockwise air flow from the low pressure system over the central Canada, along with the clockwise air flow from the high pressure system over the eastern North America, generated the southwesterly winds (see weather maps at http://www.hpc.ncep.noaa.gov/dailywxmap/). Thus, the local wind gradually shifted from the northerly winds to the southwesterly winds during this period (Figure 6). As the low pressure system continued to push into Ontario, it further reinforced the southwesterly transport of pollutants into Ontario from highly polluted area located in the Ohio River Valley in the United States as demonstrated by the variation of wind direction (Figure 6). $\mathrm{PM}_{2.5}$ data from the United States Environmental Protection Agency (http:// www.epa.gov/heasd/research/cdc.html) show high $\mathrm{PM}_{2.5}$ concentrations $\left(40-50 \mu \mathrm{g} / \mathrm{m}^{3}\right)$ on these days over part of the Ohio River Valley, south of Toronto (also see "USA Air Quality" at http://alg.umbc.edu/usaq/archives/2006_06.html). On June 18, the southwesterly flow continued as shown on the weather map at 7:00 am (Figure 7). This is a typical weather pattern that favors transport of $\mathrm{PM}_{2.5}$ from the United States to Ontario with a low pressure system (a cyclone with front) over central Canada and a high pressure system over the east coast of the United States [2]. A similar weather pattern was also found on May 30, July 26, and August 27 during high $\mathrm{PM}_{2.5}$ episodes.

In addition to transport of $\mathrm{PM}_{2.5}$, Toronto also experienced gradual elevation in ground temperature (Figure 6).
The rising temperature provided a favorable atmospheric condition to build up $\mathrm{PM}_{2.5}$ from their precursors, as increasing temperature facilitates the formation of carbonaceous species and ammonium sulfate $\left(\mathrm{ASO}_{4}\right)[10,24,25,27]$. Although increasing temperature can reduce ammonium nitrate [24-26], ammonium nitrate concentrations are usually very low (close to zero) from May to September in Canadian cities [19] and further reduction makes no big difference. Therefore, the temperature effect of enhancing $\mathrm{ASO}_{4}$ becomes dominant and the total $\mathrm{PM}_{2.5}$ concentrations increase with temperature in summer.

In phase 3, the cyclone moved further to the east. As the cold front carried clean air from the north into the region, these air masses pushed away the original stagnant warm air masses [1, 31]. Wind direction during this period shifted from 220。 (southwesterly) at 20:00 on June 18 to 280 。 (westerly) at 3:00 on June 19. In the meantime, Toronto was under the warm convey belt (WCB [13]) of the front. Rain were observed at 2:00 and 3:00 on June 19 at Toronto weather stations, as well as surrounding areas (http://climate.weather.gc.ca/). The relative humidity during the time reached almost $100 \%$ (Figure 6). Within a few hours, $\mathrm{PM}_{2.5}$ lowered from $40 \mu \mathrm{g} / \mathrm{m}^{3}$ at $21: 00$ on June 18 to $4 \mu \mathrm{g} / \mathrm{m}^{3}$ at 3:00 on June 19, 2006 (Figure 6).

In phase 4 , the cyclone approached Toronto so that the surface pressure was the lowest at 20:00 on June 19 $(987.8 \mathrm{hPa})$. After the passage of the cyclone system, the wind shifted from westerly winds into northerly winds, clear air was transported from northern Canada and thus $\mathrm{PM}_{2.5}$ was low during the time.

Trajectories were simulated to track down where the air mass came from before and after the front passage over Toronto between June 17-18 and 20-21, respectively (Figure 8). We used the Hybrid Single Particle Lagrangian Integrated Trajectory Model (HYSPLIT) (http://ready.arl.noaa.gov/HYSPLIT.php), driven by NCEP/NCAR reanalysis data from the NOAA/OAR/ESRL PSD, Boulder, Colorado, USA, at http://www.esrl.noaa.gov/psd/. Starting from June 17 at 12:00, backward trajectories from Toronto were simulated every 6 hours until June 18 at 18:00 (Figure 8(a)). Similarly, 6 backward trajectories were performed between June 20 at 0:00 and June 21 at 8:00 (Figure 8(b)). Each trajectory was run for 36 hours. During June 17-18, southwesterlies prevailed southern Ontario due to its prefront position (Figure 7) and thus air mass which reached Toronto passed over or originated from the Ohio River Valley (Figure 8(a)). However, after the passage of the front, the wind direction shifted gradually to west or northwest during June 20 and 21 (Figure 8(b)). The transport of $\mathrm{PM}_{2.5}$ and its precursors from USA stopped and $\mathrm{PM}_{2.5}$ concentrations in Toronto dropped.

3.4. Likelihood of Meteorological Differences between Clear and Polluted Air. In order to clearly distinguish meteorological influences, we chose two extreme cases in summer, a clear condition when $\mathrm{PM}_{2.5}$ range was the lowest $\left(<5 \mu \mathrm{g} / \mathrm{m}^{3}\right)$ and a heavily polluted condition when $\mathrm{PM}_{2.5}$ range was the highest $\left(>35 \mu \mathrm{g} / \mathrm{m}^{3}\right)$. First, Toronto $\left(43.71^{\circ} \mathrm{N},-79.54^{\circ} \mathrm{W}\right)$ was 


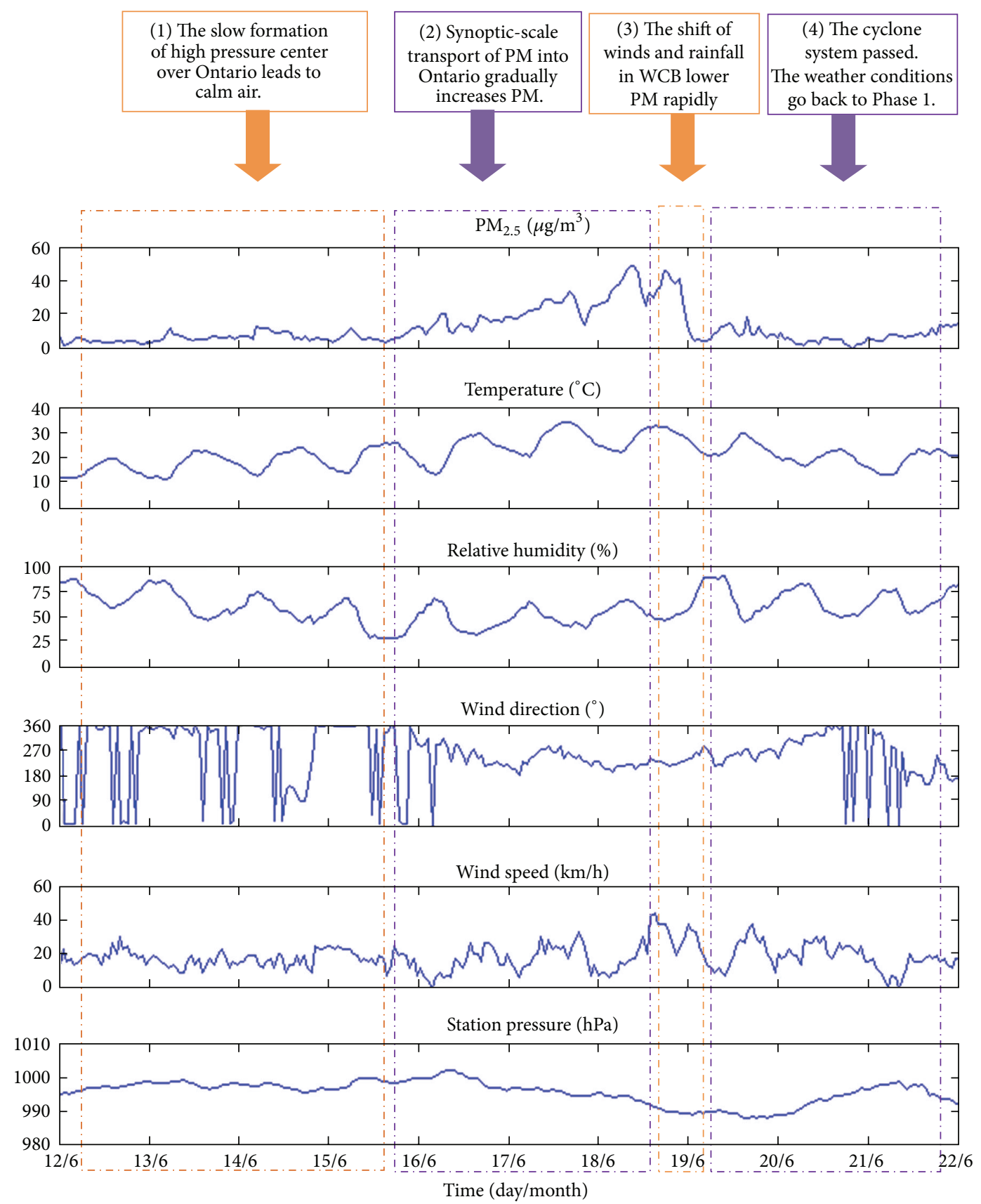

Figure 6: Hourly $\mathrm{PM}_{2.5}$ and the surface meteorological variables including air temperature $\left({ }^{\circ} \mathrm{C}\right)$, relative humidity $(\%)$, wind direction $\left({ }^{\circ}\right)$, wind speed $(\mathrm{km} / \mathrm{h})$, and surface pressure $(\mathrm{hPa})$ between June 12 and June 22, 2006, at Toronto.

chosen as an example to characterize the general probability distribution of meteorological variables under each of the two conditions (Figure 9). Second, mean meteorological differences between the two conditions were examined for the 10 cities where hourly meteorological data were available, including air temperature, relative humidity, surface pressure, and wind speed (Table 3 ).

Hourly $\mathrm{PM}_{2.5}$ data were matched with the corresponding meteorological variables in the closest meteorological station at the same city. There are 623 data for clean condition and 110 data for polluted condition between June 1, 2006, at 0:00 and
August 31, 2006, at 23:00. The bin size of $5^{\circ} \mathrm{C}$ was made for temperature from 0 to $45^{\circ} \mathrm{C}, 10 \%$ for relative humidity from 0 to $100 \%, 5 \mathrm{~km} / \mathrm{h}$ for wind speed from 0 to $50 \mathrm{~km} / \mathrm{h}, 10^{\circ}$ for wind direction from 0 to $360^{\circ}$, and $2 \mathrm{hPa}$ for surface pressure from 980 to $1010 \mathrm{hPa}$.

In each subplot of Figure 9, the horizontal axis represents the range of a meteorological variable while the vertical axis represents occurrences of the variable under one of the extreme $\mathrm{PM}_{2.5}$ conditions. Differences in the occurrence distributions are distinct between clean and polluted conditions for each meteorological variable (Figure 9). 


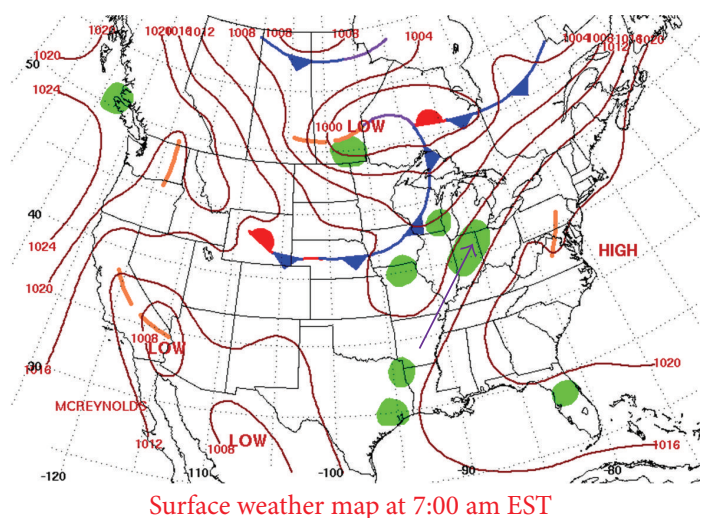

FIgUre 7: A weather map on June 18, 2006, at 7:00 am EST. The contour lines show the surface pressure and green areas are with precipitation. Fronts are in blue and red. The arrow indicates direction of winds. "High" or "Low" indicates a high pressure (anticyclone) or low pressure (cyclone) system.

Air temperature plays an active role in modulating $\mathrm{PM}_{2.5}$ concentrations. Low $\mathrm{PM}_{2.5}$ occurred more at a lower temperature peak of $15-20^{\circ} \mathrm{C}$ (Figure 9(a)), while high $\mathrm{PM}_{2.5}$ occurred more when hourly temperature peaked between 20 and $25^{\circ} \mathrm{C}$ (Figure 9(b)). In [3], it was found that although temperature may have little influence on $\mathrm{PM}_{2.5}$ when the temperature was lower than $18^{\circ} \mathrm{C}$, the influence was significant when temperature was higher than $18^{\circ} \mathrm{C}$.

The histograms of relative humidity are also distinctly different between clear and polluted air (Figures 9(c) and $9(d))$. About $50 \%$ of polluted air was with high relative humidity of $80-100 \%$, while only about $25 \%$ of clear air was in this range (Figures 9(c) and 9(d)). Relative humidity can affect $\mathrm{PM}_{2.5}$ concentrations by manipulating the particle mass and particle diameter $[11,27]$ through atmospheric physical and chemical processes. For example, under the extreme humid conditions, inorganic particles including nitrate PM can absorb water and thus increase the total particle mass [9, $24,32]$. In addition, the higher humidity promoted secondary ammonium nitrate formation and thus increased the $\mathrm{PM}_{2.5}$ concentrations $[9,24,32]$. Unlike nitrate PM, other PM components show little sensitivity to humidity [26].

$\mathrm{PM}_{2.5}$ concentrations vary with both wind speed and wind direction. High $\mathrm{PM}_{2.5}$ occurred most under slow southwesterly winds $\left(210-240^{\circ}\right)$ with wind speed of $5-10 \mathrm{~km} / \mathrm{h}$ (Figures 9(h) and 9(j)) while when wind speed was $15-20 \mathrm{~km} / \mathrm{h}$ and air mass was from the north $\left(340-360^{\circ}\right.$, $0-20^{\circ}$ ), air was mostly clean. It was reported that, as the Ohio River Valley is a region with the highest $\mathrm{PM}_{2.5}$ concentrations in North America (Figure 1), the airflow passing over the east of the Ohio River Valley has the highest PM values, while the airflow passing over Detroit-Windsor has slightly lower PM $[22,28]$. Earlier studies suggested that southern Ontario's $\mathrm{PM}_{2.5}$ concentrations were approximately $7.6 \mu \mathrm{g} / \mathrm{m}^{3}$ higher under southerlies or southwesterlies than under northerlies during the warm seasons of 1994-2003 [28]. In contrast, the fast clean northerlies from the Arctic or the strong westerlies from the Pacific in the summer can push away the polluted air and lower $\mathrm{PM}_{2.5}$ concentrations in Ontario. $\mathrm{PM}_{2.5}$ concentrations were found to be $2.2-2.3 \mu \mathrm{g} / \mathrm{m}^{3}$ higher in clusters of airflow with low wind speeds than in the clusters from the same direction with high wind speeds [28].

In addition, Figures $9(\mathrm{e})$ and $9(\mathrm{f})$ indicate that high $\mathrm{PM}_{2.5}$ episodes occurred when the surface pressure was relatively low, ranging from 988 to $996 \mathrm{hPa}$, reflecting the local transition from a high pressure system to a low pressure system shown in Figure 6 . The transition can change $\mathrm{PM}_{2.5}$ transport patterns (Figures 6 and 7) and lead to high $\mathrm{PM}_{2.5}$ concentrations at Toronto.

Table 3 provides a summary of the difference in meteorological variables between clear and heavy polluted conditions at the 10 cities. The mean air temperature was $3-6^{\circ} \mathrm{C}$ higher in polluted air at all the cities except for a northern city Thunder Bay. The mean relative humidity was $2-12 \%$ higher in polluted air at all the cities except Sudbury. Higher PM $_{2.5}$ concentrations are usually accompanied with lower surface pressure except Sarnia. When air was more stagnant, $\mathrm{PM}_{2.5}$ levels tended to be higher at 7 cites, although this was not the case at Hamilton, Sudbury, and North Bay. These exceptions suggest combined influences of different processes (e.g., regional transport and local emissions).

$\mathrm{PM}_{2.5}$ concentrations can also be influenced by precipitation as illustrated in Section 3.3. Because of lack of hourly precipitation data, the precipitation influence cannot be addressed convincingly. Future studies are required.

In short, there is no single dominant meteorological variable that can fully explain $\mathrm{PM}_{2.5}$ variability in Ontario. High $\mathrm{PM}_{2.5}$ concentrations are often associated with days when it is hot, humid, and stagnant with southerlies or southwesterlies, while low $\mathrm{PM}_{2.5}$ usually occurs when it is cool, dry, and windy with northerlies or northwesterlies. The shift between clear and polluted air is likely linked with synopticscale meteorology and regional transport of pollutants as discussed. When a site is under a prefront weather system, the $\mathrm{PM}_{2.5}$ level there tends to be high. If it is under a postfront weather system, the $\mathrm{PM}_{2.5}$ concentrations usually return to their low background levels. Precipitation generated in the WCB zone of a front can effectively scavenge the polluted air.

\section{Summary and Conclusions}

Fine particulate matter $\left(\mathrm{PM}_{2.5}\right)$ is a major pollutant that has adverse health effects. Based on $\mathrm{PM}_{2.5}$ data in 2006 at 12 cities in southern Ontario, Canada, seasonal variations of $\mathrm{PM}_{2.5}$ in the region and possible meteorological influences on the variation were investigated.

The daily $\mathrm{PM}_{2.5}$ concentrations at the 12 cities fluctuated greatly, reflecting a background $\mathrm{PM}_{2.5}$ superimposed with high $\mathrm{PM}_{2.5}$ episodes (Figure 2). The spatial variation of $\mathrm{PM}_{2.5}$ among the 12 cities illustrates combined impacts of city characteristics, local $\mathrm{PM}_{2.5}$ emission, and transboundary transport on $\mathrm{PM}_{2.5}$ (Table 1, Figures 1 and 2). Toronto, Hamilton, Windsor, and Sarnia had high annual $\mathrm{PM}_{2.5}$ 


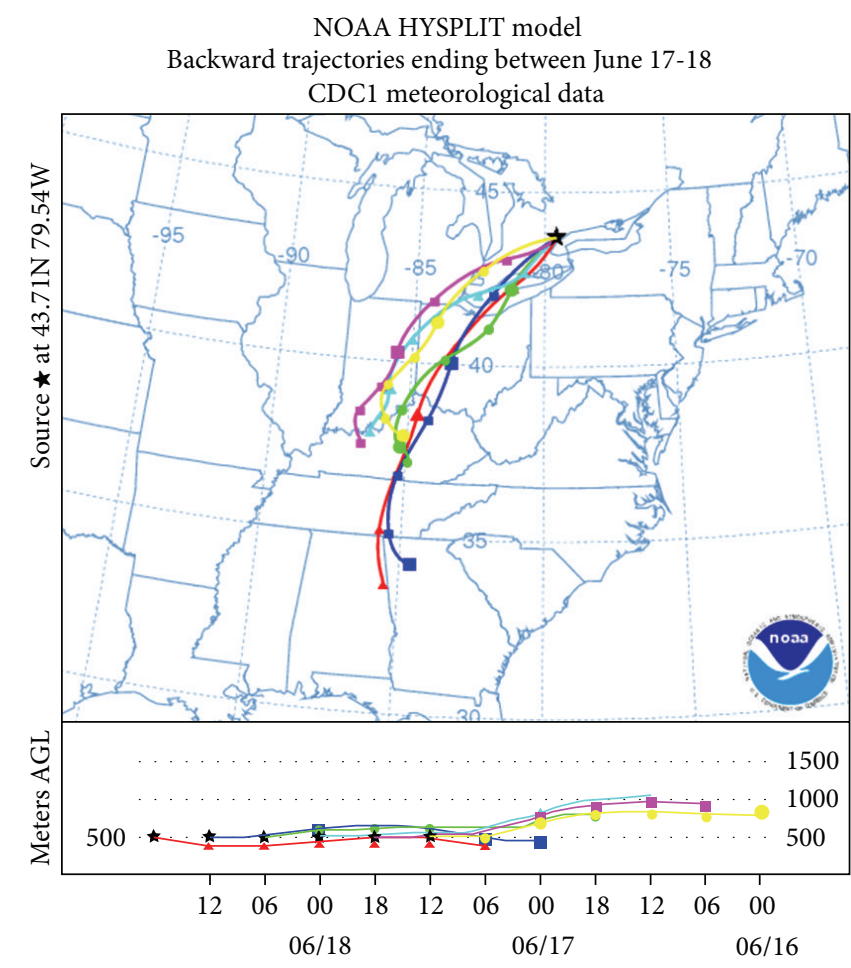

(a)

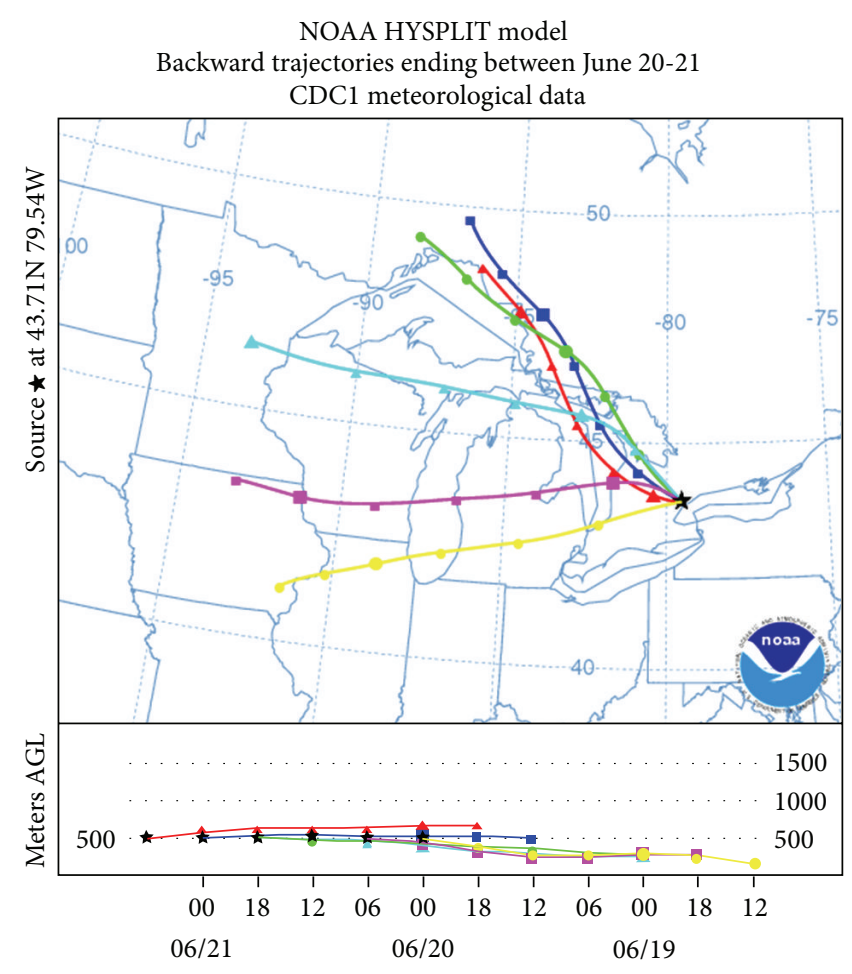

(b)

FIGURE 8: Backward trajectories starting from Toronto in every 6 hours (a) from June 17 at 12:00 UTC to June 18 at 18:00 UTC, and (b) from June 20 at 0:00 UTC to June 21 at 6:00 UTC in 2006. Every trajectory was run for 36 hours. The upper panels show horizontal movements while the lower panels show vertical movements, in which the unit for $y$-axis is meter above the ground level (AGL).

concentrations $\left(8-12 \mu \mathrm{g} / \mathrm{m}^{3}\right.$ in 2006) mainly due to their metropolitan features and/or heavy industrial activities, in addition to the influence of transboundary transport of $\mathrm{PM}_{2.5}$. Annual $\mathrm{PM}_{2.5}$ levels were low at northern cities $\left(4-6 \mu \mathrm{g} / \mathrm{m}^{3}\right.$ in 2006), including Thunder Bay, Sudbury, North Bay, and Sault Ste. Marie, where transboundary transport of $\mathrm{PM}_{2.5}$ was low although local $\mathrm{PM}_{2.5}$ emissions at Thunder Bay and Sault Ste. Marie were comparable with emissions at Toronto. In between, $\mathrm{PM}_{2.5}$ levels were intermediate $\left(6-8 \mu \mathrm{g} / \mathrm{m}^{3}\right.$ in 2006) for middle-sized cities where local $\mathrm{PM}_{2.5}$ emissions were low, lying along the transboundary pathway, including Barrie, London, Oakville, and Cornwall.

$\mathrm{PM}_{2.5}$ concentrations varied considerably from season to season in southern Ontario. Mean $\mathrm{PM}_{2.5}$ concentrations were $30-40 \%$ higher in summer $\left(7-15 \mu \mathrm{g} / \mathrm{m}^{3}\right)$ than in winter $\left(4-11 \mu \mathrm{g} / \mathrm{m}^{3}\right)$ for the 12 cities in 2006 (Figure 3). This is partly due to the fact that high $\mathrm{PM}_{2.5}$ episodes occurred more frequently in warmer seasons (Figure 4). In addition, high temperature in warmer seasons can enhance formation of $\mathrm{PM}_{2.5}$, as well as $\mathrm{PM}_{2.5}$ emissions.

Through surface meteorological condition diagnosis, weather map, and wind trajectory analyses, a weather pattern that favours transport of $\mathrm{PM}_{2.5}$ and causes $\mathrm{PM}_{2.5}$ episodes in southern Ontario is suggested (Figure 7). The weather pattern is related to development of midlatitude cyclones along with cold fronts. The synoptic transport of pollutants from highly polluted area in the United States is a major factor responsible for high $\mathrm{PM}_{2.5}$ episode events. The scavenging and ventilating functions of fronts appear to be mechanisms for cleaning air in Ontario.

Meteorology can impact $\mathrm{PM}_{2.5}$ concentrations significantly. However, there is no single dominant meteorological variable that can fully explain the interaction between meteorology and $\mathrm{PM}_{2.5}$ variability, as the variability is strongly linked with synoptic weather processes illustrated in this study. In southern Ontario, high $\mathrm{PM}_{2.5}$ is often associated with hot and humid airflow from southwest, while low $\mathrm{PM}_{2.5}$ levels often occur when it is cool and with northerly or northwesterly winds (Figure 9, Table 3). Rain generated in the WCB zone of a front can play an important role in scavenging the polluted air.

Midlatitude cyclones and their associated cold fronts are known for their ventilation function that reduces air pollution $[9,13,14]$. In this study, the role of midlatitude cyclones in transporting air pollution to Ontario is demonstrated. With possible reduction of midlatitude cyclones due to climate change, such transport will likely occur with higher PM abundances which are accumulated for longer periods. It is important to consider the long-term implications of reduction of the midlatitude cyclones on air quality in Ontario from their transport and ventilation functions.

By offering a comprehensive view on the meteorological influences on the seasonal variation of $\mathrm{PM}_{2.5}$ in southern Ontario, this study would be useful for efficient air quality 


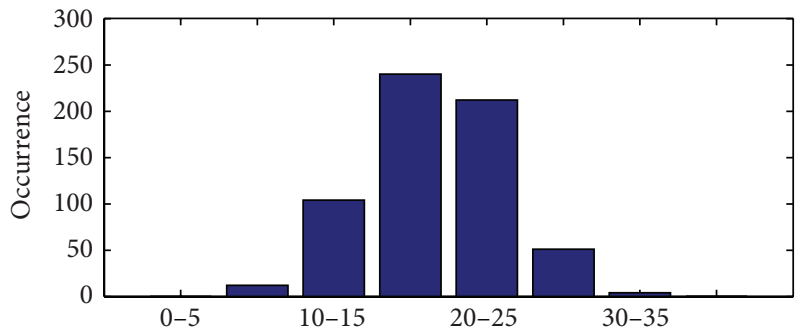

(a) Temperature $\left({ }^{\circ} \mathrm{C}\right)$

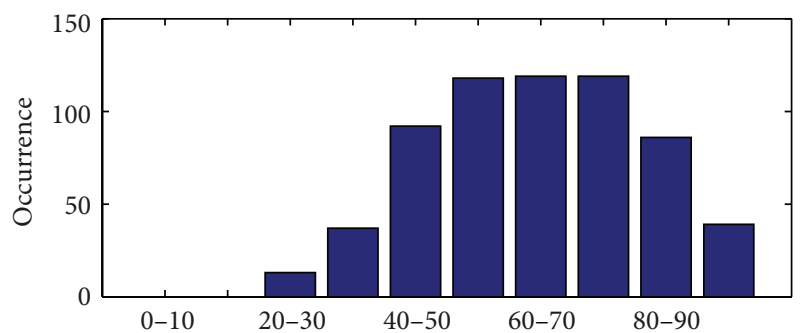

(c) Relative humidity (\%)

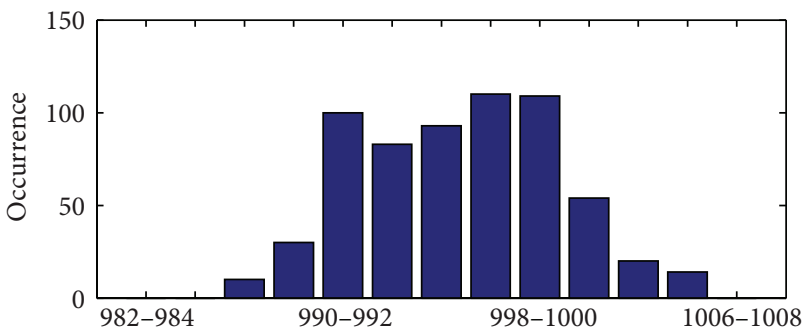

(e) Station pressure $(\mathrm{hPa})$

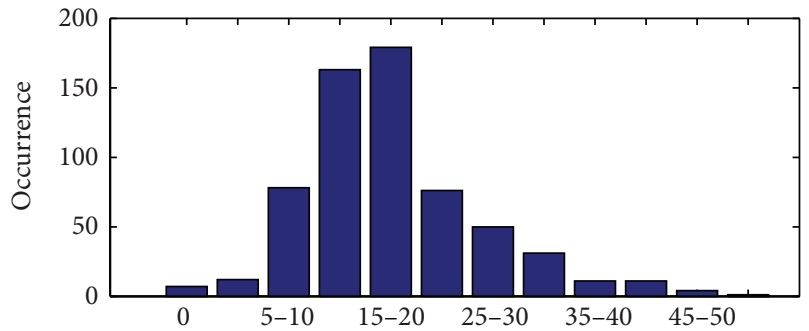

(g) Wind speed $(\mathrm{km} / \mathrm{h})$

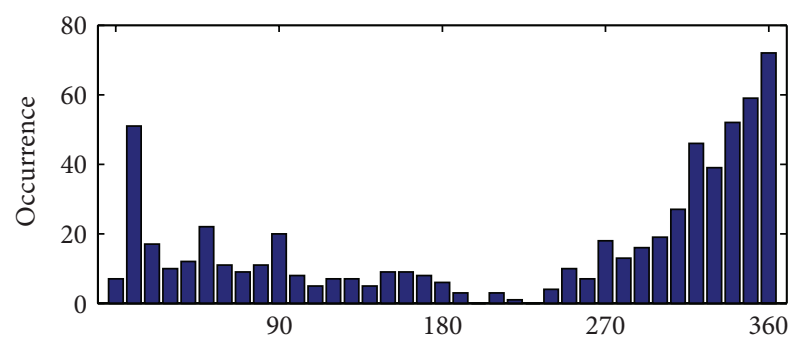

(i) Wind direction $\left({ }^{\circ}\right)$

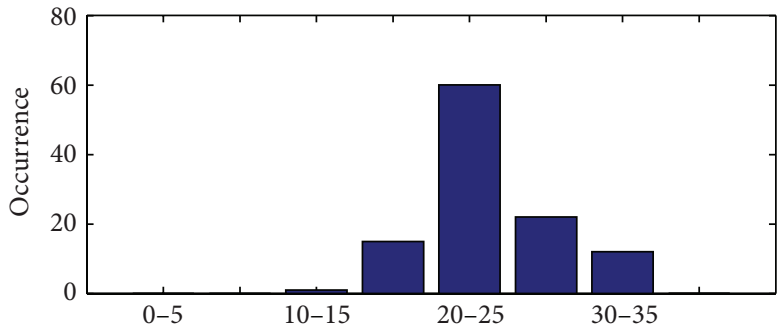

(b) Temperature $\left({ }^{\circ} \mathrm{C}\right)$

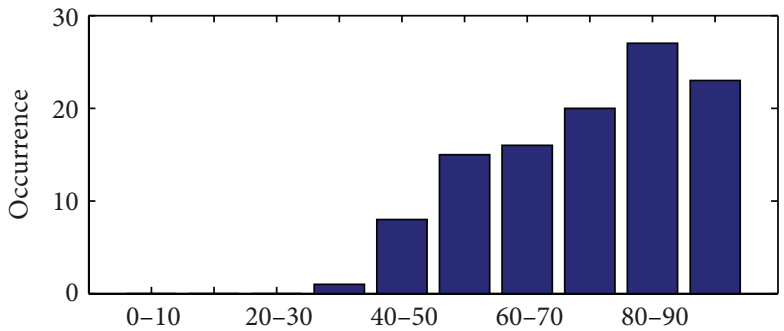

(d) Relative humidity (\%)

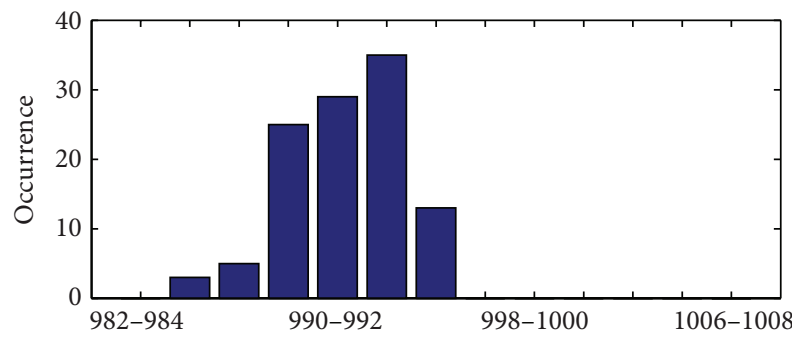

(f) Station pressure $(\mathrm{hPa})$

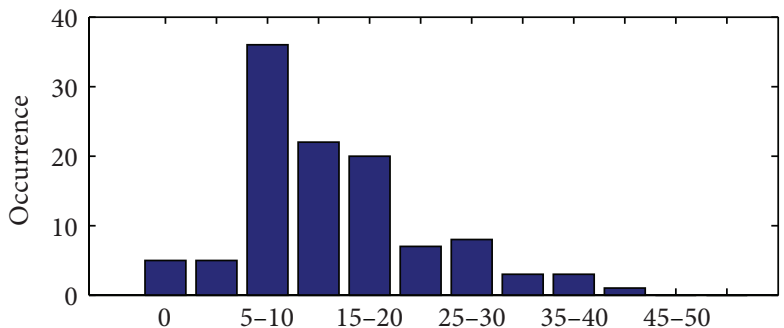

(h) Wind speed $(\mathrm{km} / \mathrm{h})$

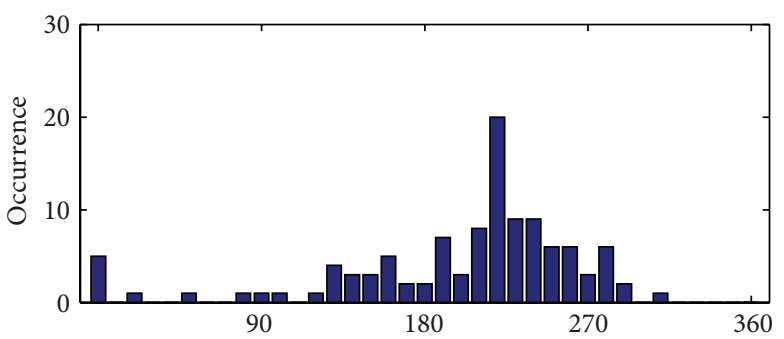

(j) Wind direction $\left({ }^{\circ}\right)$

FIGURE 9: Left: occurrence distribution of the surface meteorological conditions at Toronto in 2006 summer when hourly $\mathrm{PM}_{2.5}$ was $<5 \mu \mathrm{g} / \mathrm{m}^{3}$. Right: the same as on the left, but when hourly $\mathrm{PM}_{2.5}$ was $>35 \mu \mathrm{g} / \mathrm{m}^{3}$. 
control strategies and for timely public precautions on the weather conditions for high $\mathrm{PM}_{2.5}$ episodes.

\section{Conflict of Interests}

The authors declare that there is no conflict of interests regarding the publication of this paper.

\section{Acknowledgments}

The authors are grateful to Air Quality Ontario and Environment Canada for the $\mathrm{PM}_{2.5}$ data and meteorological data and to Randal Martin's group at University of Dalhousie for the $\mathrm{PM}_{2.5}$ data derived from satellite measurement. They acknowledge the trajectory model HYSPLIT (Hybrid Single Particle Lagrangian Integrated Trajectory Model) from the NOAA Air Resources Laboratory (http://www.arl.noaa.gov/ ready.html), driven by the NCEP/NCAR reanalysis data from the NOAA/OAR/ESRL PSD, Boulder, Colorado, USA, at http://www.esrl.noaa.gov/psd/. They thank anonymous reviewers for their constructive comments. Encouragement from Kathi Wilson at University of Toronto Mississauga is appreciated.

\section{References}

[1] C. Arden Pope III and L. S. Kalkstein, "Synoptic weather modeling and estimates of the exposure-response relationship between daily mortality and particulate air pollution," Environmental Health Perspectives, vol. 104, no. 4, pp. 414-420, 1996.

[2] D. Yap, N. Reid, G. de Brou, and R. Bloxam, “Transboundary air pollution in Ontario," Ontario Ministry of the Environment, Toronto, Canada, 2005.

[3] J. Tian and D. M. Chen, "Evaluating satellite-based measurements for mapping air quality in Ontario, Canada," Journal of Environmental Informatics, vol. 10, no. 1, pp. 30-36, 2007.

[4] M. J. Molina and L. T. Molina, "Megacities and atmospheric pollution," Journal of the Air and Waste Management Association, vol. 54, no. 6, pp. 644-680, 2004.

[5] Ontario Medical Association, The illness cost of air pollution 2005-2026 Health \& Economic Damage Estimate, 2005.

[6] J. R. Brook, C. D. Lillyman, M. F. Shepherd, and A. Mamedov, "Regional transport and urban contributions to fine particle $\left(\mathrm{PM}_{2.5}\right)$ concentrations in Southeastern Canada," Journal of Air Waste Management Association, vol. 52, pp. 174-185, 2002.

[7] J. R. Brook, D. Johnson, and A. Mamedov, "Determination of the source areas contributing to regionally high warm season $\mathrm{PM}_{2.5}$ in Eastern North America," Journal of the Air and Waste Management Association, vol. 54, no. 9, pp. 1162-1169, 2004.

[8] J. R. Brook, L. Graham, J. P. Charland et al., "Investigation of the motor vehicle exhaust contribution to primary fine particle organic carbon in urban air," Atmospheric Environment, vol. 41, no. 1, pp. 119-135, 2007.

[9] A. P. K. Tai, L. J. Mickley, D. J. Jacob et al., "Meteorological modes of variability for fine particulate matter $\left(\mathrm{PM}_{2.5}\right)$ air quality in the United States: implications for $\mathrm{PM}_{2.5}$ sensitivity to climate change," Atmospheric Chemistry and Physics, vol. 12, no. 6, pp. 3131-3145, 2012.
[10] J. Tian and D. Chen, "A semi-empirical model for predicting hourly ground-level fine particulate matter $\left(\mathrm{PM}_{2.5}\right)$ concentration in southern Ontario from satellite remote sensing and ground-based meteorological measurements," Remote Sensing of Environment, vol. 114, no. 2, pp. 221-229, 2010.

[11] D. J. Jacob and D. A. Winner, "Effect of climate change on air quality," Atmospheric Environment, vol. 43, no. 1, pp. 51-63, 2009.

[12] P. K. H. Lee, J. R. Brook, E. Dabek-Zlotorzynska, and S. A. Mabury, "Identification of the major sources contributing to $\mathrm{PM}_{2.5}$ observed in Toronto," Environmental Science and Technology, vol. 37, no. 21, pp. 4831-4840, 2003.

[13] O. R. Cooper, J. L. Moody, D. D. Parrish et al., "Trace gas signatures of the airstreams within North Atlantic cyclones: case studies from the North Atlantic Regional Experiment (NARE '97) aircraft intensive," Journal of Geophysical Research D: Atmospheres, vol. 106, no. 6, pp. 5437-5456, 2001.

[14] Q. Li, D. J. Jacob, R. Park et al., "North American pollution outflow and the trapping of convectively lifted pollution by upper-level anticyclone," Journal of Geophysical Research D: Atmospheres, vol. 110, no. 10, Article ID D10301, 2005.

[15] S. J. Lambert and J. C. Fyfe, "Changes in winter cyclone frequencies and strengths simulated in enhanced greenhouse warming experiments: results from the models participating in the IPCC diagnostic exercise," Climate Dynamics, vol. 26, no. 7-8, pp. 713-728, 2006.

[16] L. J. Mickley, D. J. Jacob, B. D. Field, and D. Rind, "Effects of future climate change on regional air pollution episodes in the United States," Geophysical Research Letters, vol. 31, no. 24, Article ID L24103, 2004.

[17] R. M. Bone, The Regional Geography of Canada, Oxford University Press, Don Millls, Ontario, Canada, 2005.

[18] D. Baldwin, J. Desloges, and L. Band, "Physical geography of Ontario," in Ecology of a Managed Terrestrial Landscape, A. Perera, D. Euler, and I. Thompson, Eds., UBC Press, 2000.

[19] E. Dabek-Zlotorzynska, T. F. Dann, P. Kalyani Martinelango et al., "Canadian National Air Pollution Surveillance (NAPS) $\mathrm{PM}_{2.5}$ speciation program: methodology and $\mathrm{PM}_{2.5}$ chemical composition for the years 2003-2008," Atmospheric Environment, vol. 45, no. 3, pp. 673-686, 2011.

[20] F. Yang, L. Huang, S. Sharma et al., "Two-year observations of fine carbonaceous particles in variable sampling intervals," Atmospheric Environment, vol. 45, no. 14, pp. 2418-2426, 2011.

[21] D. G. C. Rainham, K. E. Smoyer-Tomic, S. C. Sheridan, and R. T. Burnett, "Synoptic weather patterns and modification of the association between air pollution and human mortality," International Journal of Environmental Health Research, vol. 15, no. 5, pp. 347-360, 2005.

[22] A. van Donkelaar, R. V. Martin, M. Brauer et al., "Global estimates of ambient fine particulate matter concentrations from satellite-based aerosol optical depth: development and application," Environmental Health Perspectives, vol. 118, no. 6, pp. 847-855, 2010.

[23] J. R. Brook, T. F. Dann, and Y. Bonvalot, "Observations and interpretations from the Canadian fine particle monitoring program," Journal of the Air and Waste Management Association, vol. 49, no. 9, pp. 35-44, 1999.

[24] A. P. K. Tai, L. J. Mickley, and D. J. Jacob, "Correlations between fine particulate matter $\left(\mathrm{PM}_{2.5}\right)$ and meteorological variables in the United States: implications for the sensitivity of $\mathrm{PM}_{2.5}$ to climate change," Atmospheric Environment, vol. 44, no. 32, pp. 3976-3984, 2010. 
[25] C.-H. Jeong, G. J. Evans, P. K. Hopke, D. Chalupa, and M. J. Utell, "Influence of atmospheric dispersion and new particle formation events on ambient particle number concentration in Rochester, United States, and Toronto, Canada," Journal of the Air and Waste Management Association, vol. 56, no. 4, pp. 431443, 2006.

[26] J. P. Dawson, P. J. Adams, and S. N. Pandis, "Sensitivity of $\mathrm{PM}_{2.5}$ to climate in the Eastern US: a modeling case study," Atmospheric Chemistry and Physics, vol. 7, no. 16, pp. 4295-4309, 2007.

[27] S. C. Smyth, D. Yin, H. Roth, W. Jiang, M. D. Moran, and L.-P. Crevier, "The impact of GEM and MM5 modeled meteorological conditions on CMAQ air quality modeling results in eastern Canada and the northeastern United States," Journal of Applied Meteorology and Climatology, vol. 45, no. 11, pp. 1525-1541, 2006.

[28] D. Johnson, D. Mignacca, D. Herod, D. Jutzi, and H. Miller, "Characterization and identification of trends in average ambient ozone and fine particulate matter levels through trajectory cluster analysis in Eastern Canada," Journal of the Air and Waste Management Association, vol. 57, no. 8, pp. 907-918, 2007.

[29] S. Owega, B.-U. Khan, G. J. Evans, R. E. Jervis, and M. Fila, "Identification of long-range aerosol transport patterns to Toronto via classification of back trajectories by cluster analysis and neural network techniques," Chemometrics and Intelligent Laboratory Systems, vol. 83, no. 1, pp. 26-33, 2006.

[30] T. W. Chan and M. Mozurkewich, "Application of absolute principal component analysis to size distribution data: identification of particle origins," Atmospheric Chemistry and Physics, vol. 7, no. 3, pp. 887-897, 2007.

[31] J. T. Merrill and J. L. Moody, "Synoptic meteorology and transport during the North Atlantic Regional Experiment (NARE) intensive: overview," Journal of Geophysical Research D: Atmospheres, vol. 101, no. 22, pp. 28903-28921, 1996.

[32] C. A. Randles, L. M. Russell, and V. Ramaswamy, "Hygroscopic and optical properties of organic sea salt aerosol and consequences for climate forcing," Geophysical Research Letters, vol. 31, no. 16, 2004. 

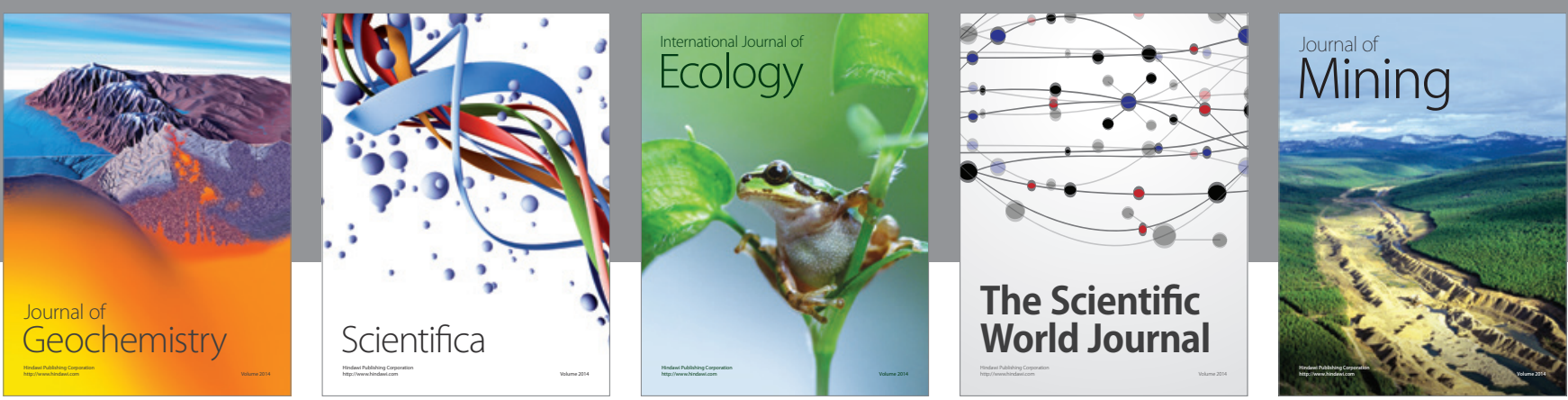

The Scientific World Journal
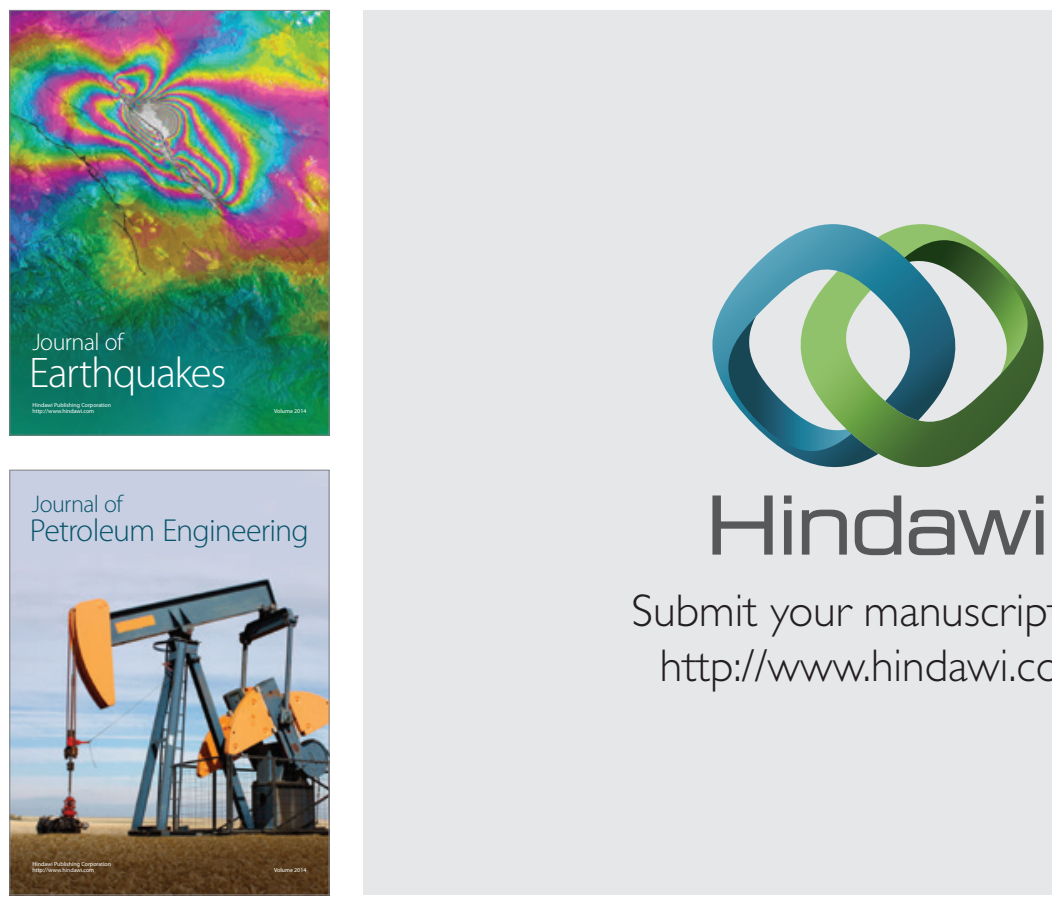

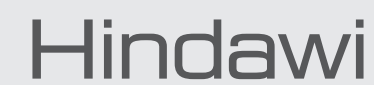

Submit your manuscripts at

http://www.hindawi.com
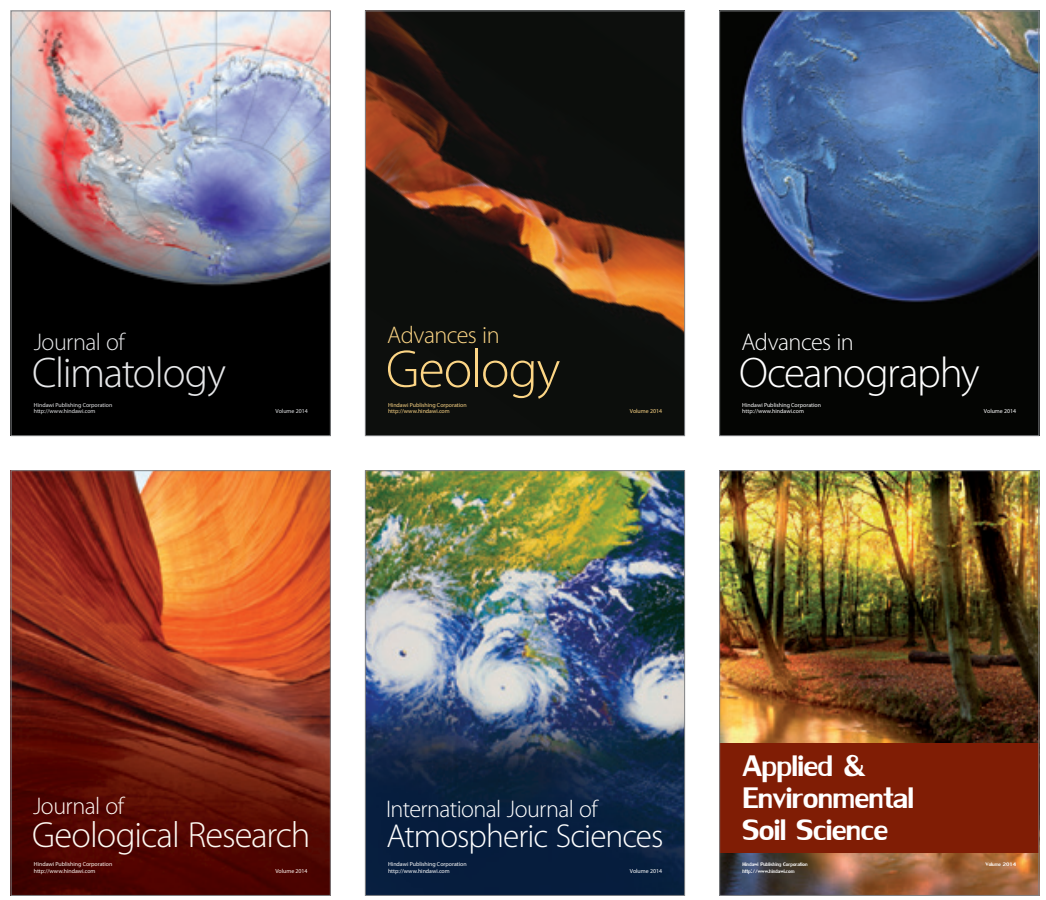
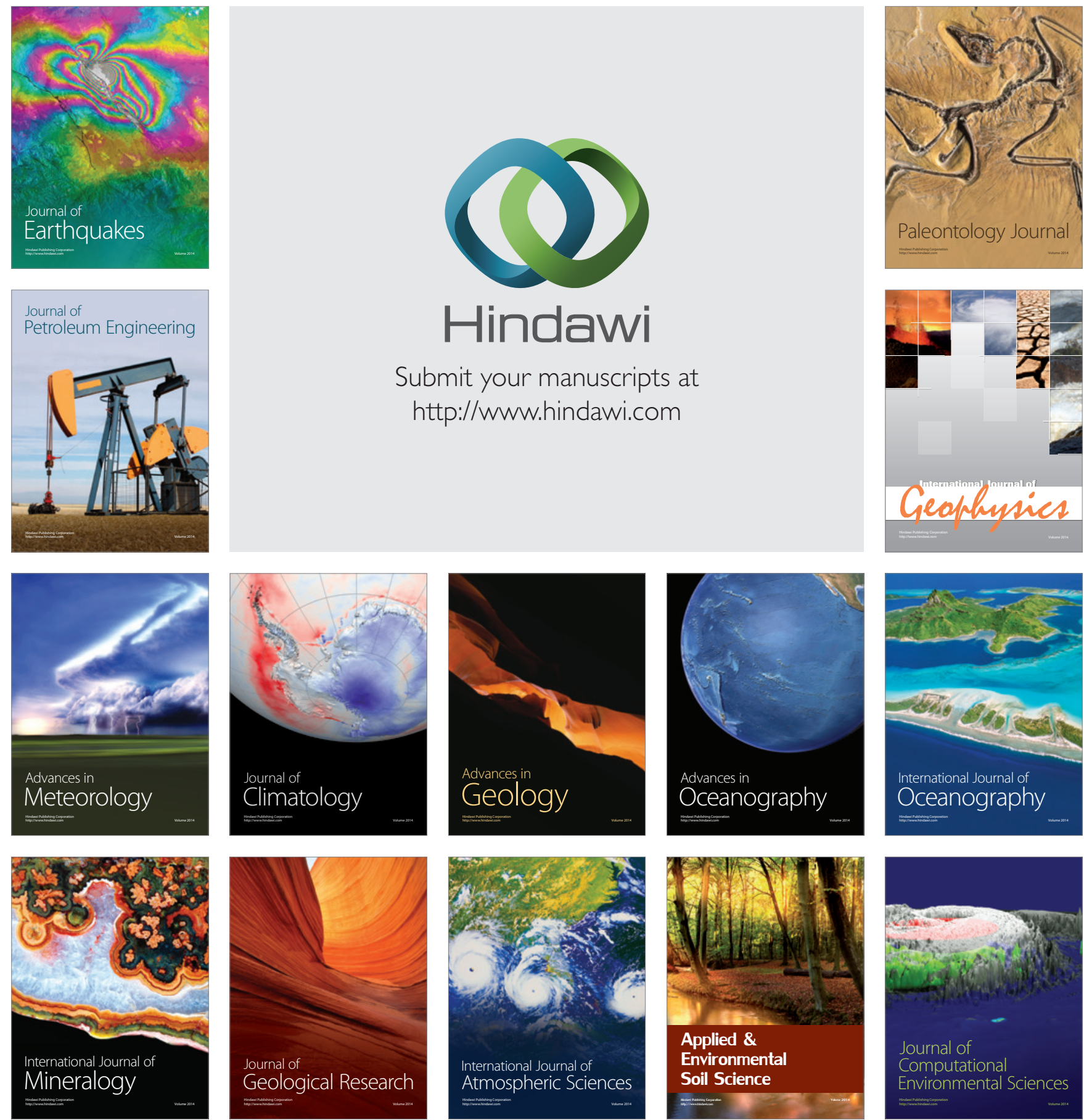